7. Reprod. Fertil. (1964) 8, 165-186

\title{
BIOLOGICAL CHARACTERISTICS OF PITUITARY AND PLACENTAL HORMONES
}

\author{
NADA KOVAC̆IC:* \\ The United Birmingham Hospitals, Department of Clinical Endocrinology, Birmingham \\ and Midland Hospital for Women, Birmingham 11
}

(Received 3rd December 1963)

\begin{abstract}
Summary. The biological characteristics of gonadotrophin and prolactin were studied by their effects upon the ovaries and the intact and damaged uterine horns of 3-month-old mice which had been hypophysectomized on the first day of dioestrus. The method, developed primarily for measuring luteotrophin by the formation of deciduomata in the damaged uterine horn, was called the deciduoma assay but it can also differentiate the activities of FSH and LH.

The decidual reaction in the damaged uterine horn appears to be a suitable endpoint for measuring ovarian progestagen released by the activity of luteotrophin, human luteinizing hormone or placental hormones. These preparations are deciduotrophic but they are not all classified as luteotrophins. The term 'luteotrophin' is reserved for preparations which cause hypertrophy of luteal cells accompanied by hyperaemia of the corpora lutea and which are deficient in other gonadotrophic activities. Only preparations of ovine prolactin and luteotrophin in human and bovine growth hormones and bovine thyrotrophin are therefore included in this group.

The deciduoma method is possibly invalid for the assay of mixtures containing relatively large amounts of FSH because the growth of follicles results in the elimination of corpora lutea. However, the method can be used to demonstrate biological differences between similar hormones and it may be of value in studies on the purification of hormones.
\end{abstract}

\section{INTRODUCTION}

The biological characteristics of pituitary and placental hormones have been studied through their effects on the ovaries and the intact and damaged uterine horns in hypophysectomized mice. The method, which has been reported elsewhere (Kovačić, 1963), was developed for the assay of luteotrophic hormone but it is also useful for differentiation of various gonadotrophic activities.

* Present address: Department of Clinical Endocrinology, Rebro, The University, Zagreb, Yugoslavia. Fellow of the World Health Organization. 


\section{MATERIALS AND METHODS}

ANIMALS

Female mice, 3 months of age, with regular oestrous cycles, were hypophysectomized on the first day of dioestrus (Day 1). The hormone was injected, in solution, immediately after the operation and on each of the next four days. On Day 3, the right uterine horn was damaged; the left horn was used as a control. On Day 6 the animals were killed and the ovaries and uterine horns were weighed. The ovaries were afterwards examined histologically.

Normal mice killed on the first day of dioestrus, and hypophysectomized mice, treated with saline, were used as controls.

\section{BIOLOGICAL PARAMETERS}

The biological properties of the gonadotrophic hormones and of prolactin were assessed by six parameters. The first two were the growth of follicles and of interstitial cells in the ovaries, indicating the activity of follicle stimulating hormone and luteinizing hormone respectively. The term 'luteinizing' is used here to refer to a hormone which stimulates ovarian interstitial cells, although it would be more correct to use the term 'interstitial cell stimulating' hormone. The morphology and size of luteal cells in the corpora lutea constitute the third parameter, being regarded as a function of luteotrophic hormone. The effects upon the intact and the damaged uterine horns constitute a further two parameters. The increase in weight of the intact horn compared with the corresponding horn of the untreated hypophysectomized mouse is an indication of uterine enlargement resulting mainly from the ovarian secretion of oestrogens. The increase in weight of the damaged horn compared with the intact horn of the same mouse is an indication of the formation of deciduomata. This is generally believed to result from the secretion of progestagen from the corpus luteum under the influence of luteotrophin. The sixth parameter is provided by the weight of the ovaries.

The mean and the standard deviation of the weights of ovaries and intact uterine horns are compared by the $t$ test. The decidual reaction in the damaged horn is measured as the percentage of positive responses, and transferred to probits. The formation of deciduomata is an 'all-or-none' phenomenon. The results are shown in tables and graphs.

The histological results were based on serial sections of four to six ovaries from each group. The ovaries were fixed in alcoholic Bouin, embedded in paraffin blocks in groups of two to four taken at random, cut in the long axis through the hilar region, and stained with haematoxylin and eosin. Uterine horns were also examined histologically. They were fixed in $4 \%$ solution of formol-saline, embedded in paraffin and stained with haematoxylin and eosin.

Pituitary hormones

HORMONE PREPARATIONS

\section{Prolactin}

(1) 2nd International Standard for Prolactin (ovine prolactin, Armour Lab., Lot No. D 14083-2B), potency 22 units/mg (Bangham, Mussett \& StackDunne, 1963). 
(2) Ovine prolactin, Armour Lab., Lot No. 759-39 BB, potency 20 to 25 units/mg.

(3) Ovine prolactin, Panlitar, Armour Lab., Lot No. s10209, potency 15 units/mg.

Follicle stimulating hormone

(4) Ovine follicle stimulating hormone, ovine standard NIH-FSH-SI, R041216.

(5) Human follicle stimulating hormone, starch gel electrophoresis fraction 4 (sG4) (Butt, Crooke, Cunningham \& Wolf, 1963).

(6) Human pituitary gonadotrophin (follicle stimulating fraction GP1), potency 3002 (95\% fiducial limits 1938 to 6956 ) $\mathrm{mg} \equiv$ IRP-HMG by the ovarian augmentation assay and 59 (41 to 86$) \mathrm{mg} \equiv$ IRP-HMG by the ventral prostate assay of the hypophysectomized rat (Butt, Crooke, Cunningham \& Kovačić, 1962).

\section{Luteinizing hormone}

(7) Ovine luteinizing hormone, NIH-LH-s4.

(8) Ovine luteinizing hormone, NIH-LH-s3.

(9) Ovine luteinizing hormone, NIH-LH-s6, Lot No. 1334.

(10) Human luteinizing hormone, IRC2 fraction, potency 1440 (710 to 2500) $\mathrm{mg} \equiv$ IRP-HMG by the ovarian ascorbic acid depletion method (the OAAD method), contains also 934 (597 to 1350 ) i.u. $\times 10^{-3} / \mathrm{mg}$ TsH (Hartree, Butt \& Kirkham, 1964).

(11) Human luteinizing hormone, DEAE-fraction 2. Potency 3750 (1780 to $8900) \mathrm{mg} \equiv$ IRP-HMG by the OAAD method, TSH $<1$ i.u. $\times 10^{-3} / \mathrm{mg}$ (Hartree et al., 1964).

(12) Human pituitary gonadotrophin (luteinizing fraction $\mathrm{CM}_{2}$ ). Potency 28 (4 to 57 ) $\mathrm{mg} \equiv$ IRP-HMG as measured by the ovarian augmentation assay and 169 (131 to 262) $\mathrm{mg} \equiv$ IRP-HMG by the ventral prostate assay of the hypophysectomized rat (Butt et al., 1962).

Growth hormone

The following preparations of human growth hormone were made by $\mathrm{Dr}$ Anne Hartree at the Department of Biochemistry, Cambridge. Their growthpromoting activity was assayed by Miss M. Thomas by increase in the body weight of hypophysectomized rats and the results were expressed in terms of the International Bovine Growth Hormone Standard. Preparations of bovine growth hormone were kindly supplied by $\mathrm{Mr}$ M. Wallis of the Department of Biochemistry, Cambridge.

(13) Human growth hormone my-61 (0.886 i.u./mg).

(14) Human growth hormone, CMC purified м12 (2.17 i.u./mg).

(15) Human growth hormone, Fraction 2, DEAE-6 (1.15 i.u./mg).

(16) Human growth hormone, Fraction 3, DEAE-6 (0.68 i.u./mg).

(17) Human growth hormone, JA-62 (1.137 i.u./mg).

(18) Bovine growth hormone 72-GH-1.

(19) Bovine growth hormone $99 \mathrm{~L}$.

Thyrotrophin

(20) Bovine thyrotrophin CMc/28/3, potency 25 i.u./mg, contaminated with small amounts of luteinizing hormone. Prepared and kindly supplied by Professor C. J. O. R. Morris, London Hospital. 
Adrenocorticotrophin

(21) ACTAR Armour Lab, FE 1401, commercial preparation, 10 usP units per ampoule.

\section{Placental hormones}

Human chorionic gonadotrophin

(22) Pregnyl Organon, commercial preparation, Lot No. 9107.

(23) Chorionic gonadotrophin Leo, Lot No. 162041, 1500 i.u./mg.

Pregnant mares' serum gonadotrophic hormone (PMS)

(24) Gestyl Organon, London, commercial preparation, Lot No. 9651 (400 units per ampoule).

(25) Gestyl Organon, London, commercial preparation, Lot No. 0048 (400 units per ampoule).

Endometrial cup secretion

(26) Extract of pony endometrial cup secretion. Potency 46 (30 to 75) $\mathrm{mg} \equiv$ IRP-HMG by the ovarian augmentation assay. The preparation was kindly supplied by Dr R. V. Short, the Veterinary School, Cambridge.

All preparations were dissolved in $0.9 \%$ saline before use and kept in a refrigerator.

\section{RESULTS}

\section{Normal mice}

CONTROL GROUPS

They were examined on the first day of dioestrus. The mean weight of the left uterine horn was $50.4 \pm 9.34 \mathrm{mg}$ and of the ovaries $17.2 \pm 5.88 \mathrm{mg}$.

Most of the ovarian follicles were at the primary stage and only a few reached medium size. Corpora lutea were of different ages. Fresh corpora lutea of ovulation had large luteal cells arranged in mesh-like cords which were divided by rather wide capillary spaces. Luteal cells had well-defined boundaries, a finely granular cytoplasm and vesicular nuclei. The other corpora lutea were composed of somewhat smaller cells. Interstitial cells were present but small, with pale and finely granular cytoplasm and vesicular nuclei.

\section{Hypophysectomized mice}

The mean weight of the intact horn was $25.2 \pm 5.39 \mathrm{mg}$ and of the ovaries $10.4 \pm 3.95 \mathrm{mg}$, and the loss of weight compared with normal mice was highly significant $(P<0.001)$. The weights of intact horns and ovaries in several groups of hypophysectomized mice treated with saline were constant $(P>0.05)$ during 2 years of observations. There were no deciduomata in the damaged horn.

Ovarian follicles remained small, most were in the primary stage and only a few were larger, with small antra. Corpora lutea were numerous and well defined. The cord-like arrangement of luteal cells was retained but the capillary spaces were narrow and the overall impression was of a greater density of luteal cells. Their cytoplasm appeared less granular but the nuclei were vesicular. Interstitial cells were atrophic (Pl. 1, Fig. 1). 
PITUITARY HORMONES

Prolactin (Table 1; Text-fig. 1; Pl. 1, Fig. 2)

Prolactin was assayed at dosages of 65, 130 and $260 \mu \mathrm{g}$ per mouse. It induced the formation of deciduomata in the damaged horn and there was a positive correlation between dosage and decidual response. Ovarian weights were

\section{TABLE 1}

HYPOPHYSECTOMIZED MIGE TREATED WITH PROLAGTIN; EFFEGT OF INCREASING DOSAGES OF PROLAGTIN UPON MEAN WEIGHT OF OVARIES COMPARED WITH CONTROL GROUP

\begin{tabular}{|c|c|c|c|c|c|}
\hline Group & $\begin{array}{c}\text { No. } \\
\text { animals }\end{array}$ & $\begin{array}{l}\text { Dose } \\
(\mu g)\end{array}$ & $\begin{array}{c}\text { Ovaries mean } \\
\text { wt }(m g) \pm \text { s.D. }\end{array}$ & $t$ & $P$ \\
\hline Control & 20 & & $10.4 \pm 3.95$ & & \\
\hline Second International Standard Prolactin & $\begin{array}{l}15 \\
23 \\
16\end{array}$ & $\begin{array}{r}65 \\
130 \\
260\end{array}$ & $\begin{array}{r}8.6 \pm 3.01 \\
11 \cdot 4 \pm 3.97 \\
11 \cdot 8 \pm 4.77\end{array}$ & $\begin{array}{r}-1.495 \\
0.923 \\
0.968\end{array}$ & $\begin{array}{l}0.2 \text { to } 0.1 \\
0.4 \text { to } 0.3 \\
0.4 \text { to } 0.3\end{array}$ \\
\hline Ovine Prolactin; Armour 759-39 BB & $\begin{array}{l}20 \\
20 \\
20\end{array}$ & $\begin{array}{r}65 \\
130 \\
260\end{array}$ & $\begin{array}{c}9 \cdot 8 \pm 3 \cdot 0 \\
11 \cdot 1 \pm 4 \cdot 46 \\
12 \cdot 2 \pm 2 \cdot 67\end{array}$ & $\begin{array}{r}-0.496 \\
0.551 \\
1.681\end{array}$ & $\begin{array}{c}0.7 \text { to } 0.6 \\
0.6 \text { to } 0.5 \\
0.1\end{array}$ \\
\hline $\begin{array}{l}\text { Ovine Prolactin (Panlitar); Armour } \\
\text { s } 10209\end{array}$ & $\begin{array}{l}20 \\
13 \\
20\end{array}$ & $\begin{array}{r}65 \\
130 \\
260\end{array}$ & $\begin{array}{l}9 \cdot 6 \pm 3 \cdot 77 \\
9 \cdot 8 \pm 3 \cdot 39 \\
9 \cdot 8 \pm 2 \cdot 89\end{array}$ & $\begin{array}{l}-0.623 \\
-0.469 \\
-0.534\end{array}$ & $\begin{array}{c}0.6 \text { to } 0.5 \\
0.7 \text { to } 0.6 \\
0.6\end{array}$ \\
\hline
\end{tabular}

reduced to the level of saline-treated hypophysectomized controls; there was a tendency towards bigger weights at higher dosages of some preparations but this was not significant $(P>0.05)$. The weights of the intact uterine horns did

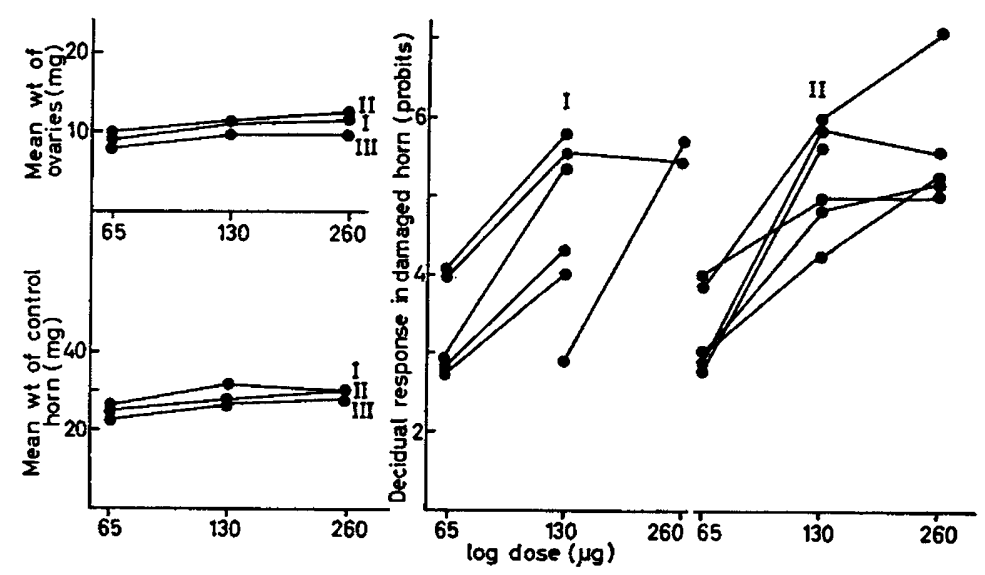

TEXT-FIG. 1. Hypophysectomized mice treated with prolactin. I. 2nd International Standard for Prolactin. II. Ovine prolactin, Armour Lab., Lot 759-39 вB. III. Panlitar, Armour Lab. Lot s 10209. Dose-response curves of the ovaries and uterine horns.

not differ from those of the hypophysectomized controls at low dosages but at high dosages there was a slight but significant increase $(P=0.05$ to 0.02$)$ (Kovačić, 1963). 
All preparations of prolactin caused similar changes in the ovaries of mice at a dose of $260 \mu \mathrm{g}$. Follicles were mainly at the primary stage and only a few were larger and contained small antra. Corpora lutea were numerous and well shaped. A varying number of them had large luteal cells arranged in mesh-like cords separated by wide capillary spaces. The cells had finely granular or foamy, pale eosinophilic cytoplasm, vesicular nuclei and well-defined boundaries. Two of the preparations caused complete atrophy of the interstitial cells and the third preparation had a similar but less marked effect.

\section{Follicle stimulating hormone}

Ovine follicle stimulating hormone (Tables 2 and 3; Text-fig. 2; Pl. 1, Fig. 3). This preparation was assayed at dosages of $125,250,500$ and $1000 \mu \mathrm{g}$ respectively. Ovarian and uterine weights increased significantly at higher dosage levels but no deciduomata were produced.

\section{TABLE 2}

HYPOPHYSECTOMIZED MICE TREATED WITH PREPARATIONS OF OVINE AND HUMAN FOLLIGLE STIMULATING HORMONE; EFFEGT OF INGREASING DOSAGES OF FSH UPON MEAN WEIGHT OF INTACT HORNS OF UTERUS GOMPARED WITH GONTROL GROUP

\begin{tabular}{|c|c|c|c|c|c|}
\hline Group & $\begin{array}{c}\text { No. } \\
\text { animals }\end{array}$ & $\underset{\substack{\text { Dose }(m g) \\
\text { IR-HMG } \\
(\mu g)}}{ }$ & $\begin{array}{l}\text { Intact horn } \\
\text { mean wt } \\
(m g) \pm \text { S.D. }\end{array}$ & $t$ & $P$ \\
\hline Control & 5 & & $25 \cdot 4 \pm 4 \cdot 21$ & & \\
\hline NIH-FSH-S1 (ovine) & $\begin{array}{l}3 \\
3 \\
5 \\
3\end{array}$ & $\begin{array}{r}125 \\
250 \\
500 \\
1000\end{array}$ & $\begin{array}{l}34 \cdot 4 \pm 13 \cdot 3 \\
25 \cdot 9 \pm 4 \cdot 47 \\
48 \cdot 2 \pm 31 \cdot 6 \\
68 \cdot 8 \pm 28 \cdot 5\end{array}$ & $\begin{array}{l}1.403 \\
0.156 \\
1.579 \\
3.53\end{array}$ & $\begin{array}{l}0.2 \text { to } 0.1 \\
0.9 \text { to } 0.8 \\
0.2 \text { to } 0.1 \\
0.02 \text { to } 0.01\end{array}$ \\
\hline Human pituitary FsH (sG4) & $\begin{array}{l}5 \\
3 \\
4\end{array}$ & $\begin{array}{l}20^{*} \\
40^{*} \\
80^{*}\end{array}$ & $\begin{array}{l}22 \cdot 8 \pm 4 \cdot 89 \\
39 \cdot 9 \pm 22 \cdot 41 \\
91 \cdot 7 \pm 11 \cdot 83\end{array}$ & $\begin{array}{r}-0.904 \\
1.483 \\
11.798\end{array}$ & $\begin{array}{l}0.3 \text { to } 0.4 \\
0.2 \\
<0.001\end{array}$ \\
\hline Control & 5 & & $26 \cdot 6 \pm 6 \cdot 0$ & & \\
\hline $\begin{array}{l}\text { Human pituitary gonadotrophin } \\
\text { FSH fraction CP1 }\end{array}$ & $\begin{array}{l}5 \\
3\end{array}$ & $\begin{aligned} 88 * \\
176^{*}\end{aligned}$ & $\begin{array}{l}107 \cdot 9 \pm 20 \cdot 4 \\
119 \cdot 1 \pm 2 \cdot 83\end{array}$ & $\begin{array}{r}8 \cdot 84 \\
33 \cdot 67\end{array}$ & $\begin{array}{l}<0.001 \\
<0.001\end{array}$ \\
\hline
\end{tabular}

* $\mathrm{mg}=$ IRP-HMG measured by the ovarian augmentation assay.

The ovaries of mice given 250 and $500 \mu g$ were examined histologically. In the former the follicles were small and the histological picture resembled that of the control group, but in the latter some ovaries were larger and showed a predominance of large Graafian follicles, while corpora lutea were greatly reduced in number and had close-packed luteal cells. In others the ovaries were small and, apart from having a few growing follicles, were similar to the control group. This variation occurred because the dosage was just at the threshold level of the response. Interstitial cells were atrophic in both groups.

Human follicle stimulating hormone (sG4) (Tables 2 and 3; Text-fig. 2). The preparation was assayed at dosages of 20,40 and $80 \mathrm{mg} \equiv$ IRP-HMG per mouse. The lowest dosage was ineffective and the two higher dosages caused a gradual and significant rise in both the ovarian and the uterine weights $(P<0.01$ and 
$<0.001$ respectively) but the decidual response was negative. The slope of the uterine weight curve was steep.

At the lowest dosage the ovaries resembled those of the control group and at the next they contained about an equal number of Graafian follicles and corpora

TABLE 3

HYPOPHYSEGTOMIZED MICE TREATED WTTH PREPARATIONS OF OVINE AND HUMAN FOLLICLE STIMULATING HORMONE; EFFECT OF INGREASING DOSAGES OF FSH UPON MEAN WEIGHT OF OVARIES COMPARED WTTH CONTROL GROUP

\begin{tabular}{|c|c|c|c|c|c|}
\hline Group & $\begin{array}{c}\text { No. } \\
\text { animals }\end{array}$ & $\begin{array}{c}\text { Dose }(m g) \equiv \\
\underset{\text { IRP-HMG }}{(\mu g)}\end{array}$ & $\begin{array}{c}\text { Ovaries mean } \\
w t(m g) \pm \text { s.D. }\end{array}$ & $t$ & $P$ \\
\hline Control & 5 & & $9 \cdot 2 \pm 2 \cdot 81$ & & \\
\hline NIH-FSH-sI (ovine) & $\begin{array}{l}3 \\
3 \\
5 \\
3\end{array}$ & $\begin{array}{r}125 \\
250 \\
500 \\
1000\end{array}$ & $\begin{aligned} 13 \cdot 7 \pm 5 \cdot 77 \\
9 \cdot 7 \pm 2 \cdot 41 \\
14 \cdot 3 \pm 6 \cdot 9 \\
19 \cdot 7 \pm 5 \cdot 14\end{aligned}$ & $\begin{array}{l}0.772 \\
0.251 \\
1.517 \\
3.82\end{array}$ & $\begin{array}{l}0.5 \text { to } 0.4 \\
0.8 \text { to } 0.9 \\
0.1 \text { to } 0.2 \\
0.01\end{array}$ \\
\hline Human pituitary FsH (sG4) & $\begin{array}{l}5 \\
3 \\
4\end{array}$ & $\begin{array}{l}20^{*} \\
40^{*} \\
80^{*}\end{array}$ & $\begin{array}{r}7 \cdot 8 \pm 1 \cdot 71 \\
14 \cdot 8 \pm 2 \cdot 31 \\
19 \cdot 6 \pm 4 \cdot 96\end{array}$ & $\begin{array}{r}-0.952 \\
2.868 \\
3.974\end{array}$ & $\begin{array}{l}0.3 \text { to } 0.4 \\
0.05 \text { to } 0.02 \\
0.01 \text { to } 0.001\end{array}$ \\
\hline Control & 5 & & $10 \cdot 3 \pm 3 \cdot 12$ & & \\
\hline $\begin{array}{l}\text { Human pituitary gonadotrophin } \\
\text { FSH fraction CP1 }\end{array}$ & $\begin{array}{l}5 \\
3\end{array}$ & $\begin{array}{l}88^{*} \\
176^{*}\end{array}$ & $\begin{array}{l}34 \cdot 8 \pm 11 \cdot 49 \\
31.9 \pm 11 \cdot 0\end{array}$ & $\begin{array}{l}4 \cdot 83 \\
4 \cdot 598\end{array}$ & $\begin{array}{l}0.01 \text { to } 0.001 \\
0.01 \text { to } 0.001\end{array}$ \\
\hline
\end{tabular}
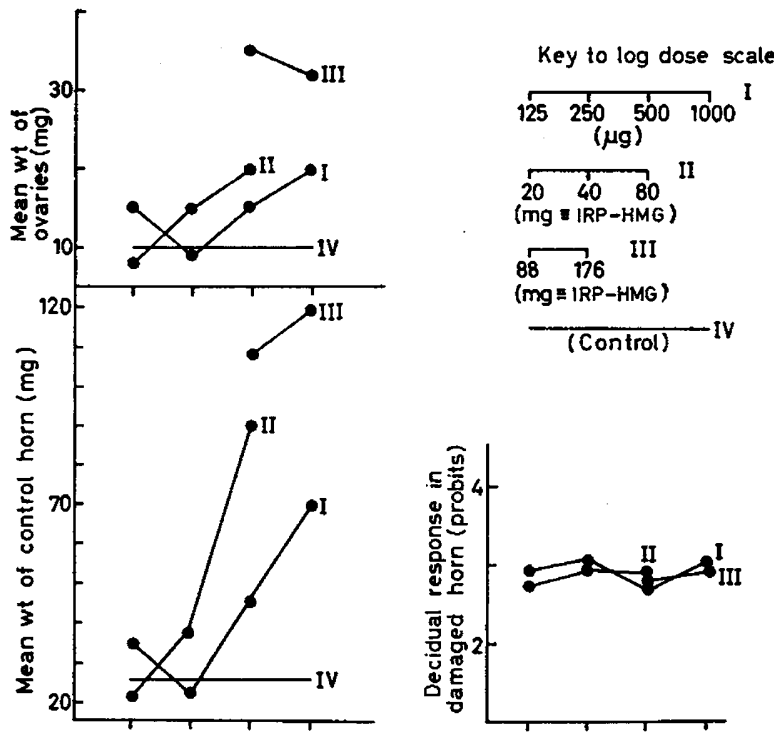

(mg $\equiv$ IRP-HMG)
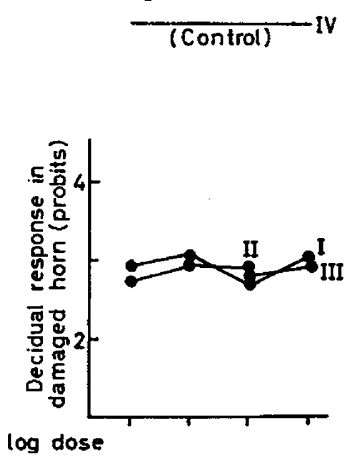

TEXT-FIG. 2. Hypophysectomized mice treated with follicle stimulating hormone. I. Ovine pituitary FSH (NIH-FSH-S1). II. Human pituitary FSH (SG4). III. Human pituitary gonadotrophin (FSH fraction CP1). IV. Control group. Dose-response curves of the ovaries and uterine horns. 
lutea. Cords of luteal cells were close and the cells were small. In mice given 80 $\mathrm{mg} \equiv \mathrm{IRP}-\mathrm{HMG}$ the ovaries were mostly composed of large, but not fully matured, Graafian follicles. The antra were rather large and the membrana granulosa was three to four layers thick. The corpora lutea were greatly reduced in number and size and only a few appeared normal. Most had lost their normal structure and contained rather small luteal cells. The interstitial cells were atrophic. The ovaries were histologically similar to those of mice given ovine follicle stimulating hormone shown on Pl. 1, Fig. 3.

Human pituitary gonadotrophin (follicle stimulating fraction $\mathrm{CP}_{1}$ ) (Tables 2 and 3 ). This preparation was tested at 88 and $176 \mathrm{mg} \equiv$ IRP-HMG. Ovarian and uterine weights were greatly increased and the decidual response was negative.

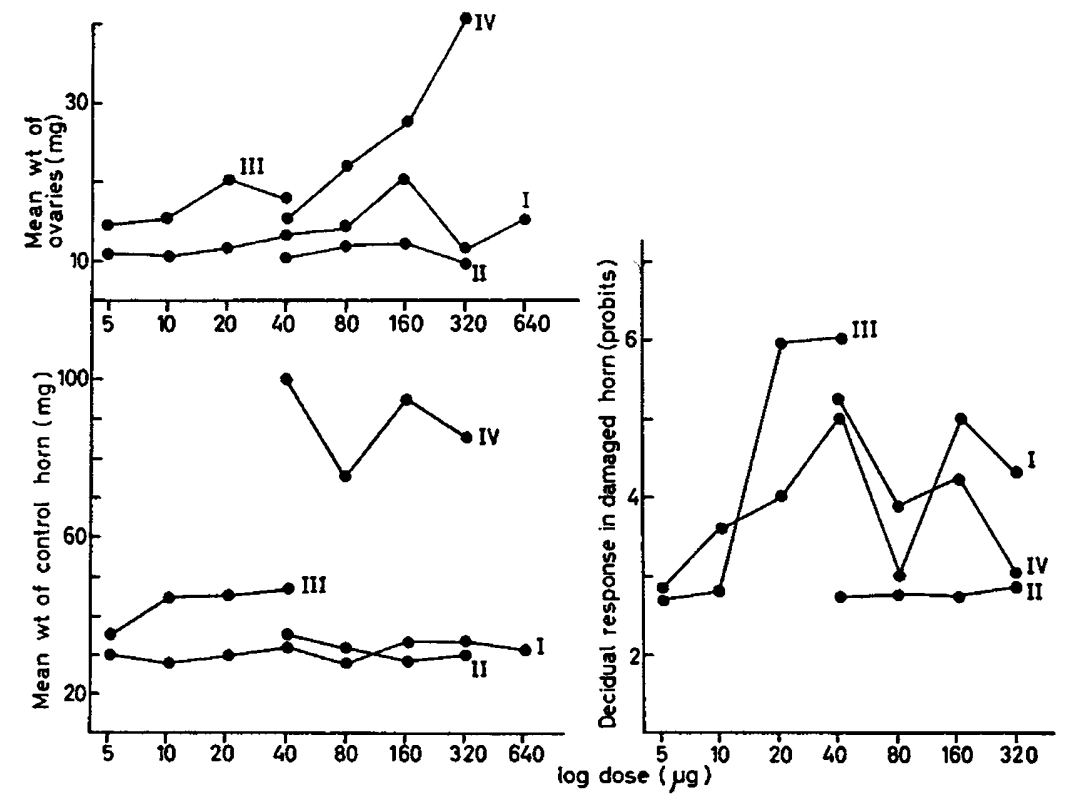

TexT-FIG. 3. Hypophysectomized mice treated with luteinizing hormone. I and II. Results of assays from two vials each labelled as NIH-LH-S4. III. Human pituitary LH (IRC 2 fraction). IV. Human pituitary gonadotrophin (luteinizing fraction $\mathrm{CM}_{2}$ ). Dose-response curves of the ovaries and uterine horns.

At the lower dosage the ovaries contained Graafian follicles and corpora lutea with small luteal cells and normal interstitial cells. At the higher dosage Graafian follicles dominated the picture while corpora lutea were scarce. The cells of the theca interna were hypertrophied, the luteal cells were of medium size, and some had granular or foamy cytoplasm and well-defined cell boundaries. Interstitial cells were slightly enlarged.

\section{Luteinizing hormone}

Ovine luteinizing hormone (Tables 4 and 5; Text-fig. 3; Pl. 1, Fig. 4). Three different batches of ovine luteinizing hormone were assayed. The first preparation, NIH-LH-S4, was tested from two separate vials, one in the dosage range of between 5 and $640 \mu \mathrm{g}$ and the other between 40 and $320 \mu \mathrm{g}$. There was a slight increase in the weight of the intact uterine horn but this was not significant 
$(P>0.05)$ except at the two highest dosage levels from one vial $(P=0.05$ to $0.01)$. The ovarian weight remained at the control level at all dosages $(P>0.05)$, with one exception. The decidual response was produced with hormone from one vial but not from the other. Deciduomata first occurred in mice given $10 \mu \mathrm{g}$ but the response was generally small. The slope of the dose-response curve rose slowly and was not parallel to that of ovine prolactin $(P<0 \cdot 05)$.

TABLE 4

HYPOPHYSEGTOMIZED MICE TREATED WITH PREPARATIONS OF OVINE AND HUMAN LUTEINIZING HORMONE; EFFECT OF INCREASING DOSAGES OF LH UPON MEAN WEIGHT OF INTACT UTERINE HORNS GOMPARED WITH CONTROL GROUP

\begin{tabular}{|c|c|c|c|c|c|}
\hline Group & $\begin{array}{c}\text { No. } \\
\text { animals }\end{array}$ & Dose $(\mu g)$ & $\begin{array}{l}\text { Intact horn mean } \\
w t(m g) \pm \text { S.D. }\end{array}$ & $t$ & $P$ \\
\hline Control & 5 & & $25 \cdot 4 \pm 4 \cdot 21$ & & \\
\hline Ovine Ін NIH-LH-s4 & $\begin{array}{r}6 \\
11 \\
8 \\
4 \\
3 \\
4 \\
4 \\
3\end{array}$ & $\begin{array}{r}5 \\
10 \\
20 \\
40 \\
80 \\
160 \\
320 \\
640\end{array}$ & $\begin{array}{l}29.9 \pm 5.32 \\
29.3 \pm 7.37 \\
30.2 \pm 7.87 \\
31.4 \pm 7.57 \\
27.8 \pm 9.25 \\
31.8 \pm 7.27 \\
33.0 \pm 2.70 \\
32.2 \pm 2.46\end{array}$ & $\begin{array}{l}0.521 \\
1.077 \\
1.241 \\
1.508 \\
0.509 \\
1.651 \\
3.09 \\
2.492\end{array}$ & $\begin{array}{l}0.7 \text { to } 0.6 \\
0.3 \\
0.3 \text { to } 0.2 \\
0.2 \text { to } 0.1 \\
0.7 \text { to } 0.6 \\
0.2 \text { to } 0.1 \\
0.02 \text { to } 0.01 \\
0.05 \text { to } 0.02\end{array}$ \\
\hline $\begin{array}{l}\text { Ovine LH NHH-LH-S4 repeated } \\
\text { assay }\end{array}$ & $\begin{array}{l}5 \\
6 \\
6 \\
4\end{array}$ & $\begin{array}{r}40 \\
80 \\
160 \\
320\end{array}$ & $\begin{array}{l}31.9 \pm 11 \cdot 75 \\
29 \cdot 4 \pm 8 \cdot 58 \\
28.5 \pm 5 \cdot 51 \\
31.9 \pm 6.39\end{array}$ & $\begin{array}{l}1 \cdot 170 \\
0.926 \\
1.004 \\
1.854\end{array}$ & $\begin{array}{cl} & 0.3 \\
0.4 & \text { to } 0.3 \\
0.4 & \text { to } 0.3 \\
0.1\end{array}$ \\
\hline Ovine LH NIH-LH-s3 & 3 & 466 & $33 \cdot 1 \pm 4 \cdot 69$ & $2 \cdot 391$ & 0.1 to 0.05 \\
\hline Control & 5 & & $27 \cdot 9 \pm 8 \cdot 25$ & & \\
\hline Ovine LH NIH-LH-s6 & $\begin{array}{l}9 \\
2\end{array}$ & $\begin{array}{l}1000 \\
2000\end{array}$ & $\begin{array}{l}40 \cdot 2 \pm 8 \cdot 28 \\
26 \cdot 0\end{array}$ & $2 \cdot 66$ & $0 \cdot 02$ \\
\hline Control & 5 & & $25 \cdot 4 \pm 4 \cdot 21$ & & \\
\hline Human LH IRC2 & $\begin{array}{l}6 \\
4 \\
6 \\
6\end{array}$ & $\begin{array}{r}5 \\
10 \\
20 \\
40\end{array}$ & $\begin{array}{l}35 \cdot 1 \pm 6 \cdot 51 \\
44 \cdot 5 \pm 16 \cdot 34 \\
44 \cdot 7 \pm 22 \cdot 0 \\
45 \cdot 7 \pm 11 \cdot 23\end{array}$ & $\begin{array}{l}3 \cdot 206 \\
2 \cdot 548 \\
1.916 \\
3.786\end{array}$ & $\begin{array}{c}0.01 \\
0.05 \text { to } 0.02 \\
0.05 \text { to } 0 \cdot 1 \\
0.01 \text { to } 0.001\end{array}$ \\
\hline Human LH DEAE-fraction 2 & $\begin{array}{l}3 \\
4 \\
2\end{array}$ & $\begin{array}{l}10 \\
20 \\
40\end{array}$ & $\begin{array}{l}46 \cdot 3 \pm 9 \cdot 13 \\
42 \cdot 8 \pm 20 \cdot 22 \\
71 \cdot 3\end{array}$ & $\begin{array}{l}2.374 \\
1.907\end{array}$ & $\begin{array}{c}0.1 \text { to } 0.05 \\
0.1\end{array}$ \\
\hline $\begin{array}{l}\text { Human pituitary gonadotrophin } \\
\text { LH fraction } \mathbf{C M}_{2}\end{array}$ & $\begin{array}{l}5 \\
7 \\
4 \\
3\end{array}$ & $\begin{array}{r}40 \\
80 \\
160 \\
320\end{array}$ & $\begin{array}{c}101 \cdot 5 \pm 18 \cdot 24 \\
77 \cdot 2 \pm 27 \cdot 6 \\
95 \cdot 6 \pm 24 \cdot 94 \\
87 \cdot 9 \pm 24 \cdot 37\end{array}$ & $\begin{array}{l}9 \cdot 09 \\
4 \cdot 10 \\
6 \cdot 29 \\
5 \cdot 91\end{array}$ & $\begin{array}{c}<0.001 \\
0.01 \text { to } 0.001 \\
<0.001 \\
0.001\end{array}$ \\
\hline
\end{tabular}

NIH-LH-S3 was assayed at a dosage level of $466 \mu \mathrm{g}$. Only one animal out of three gave a slight decidual response.

NIH-LH-s6 was tested at dosages of 1000 and $2000 \mu \mathrm{g}$. The ovarian and the uterine weights were moderately increased $(P<0.05)$ but only one mouse out of nine gave a slight decidual response at the dosage of $1000 \mu \mathrm{g}$ and two were negative at $2000 \mathrm{mg}$. 
In ovaries of mice given $640 \mu \mathrm{g}$ NH-LH-s4, follicles remained small and only a few contained small antra. Some relatively large corpora lutea were present. Most of them contained small densely-arranged luteal cells but a few were composed of slightly larger luteal cells with pale finely granular cytoplasm. Interstitial cells were similar to those in normal ovaries.

\section{TABLe 5}

HYPOPHYSEGTOMIZED MICE TREATED WITH PREPARATIONS OF OVINE AND HUMAN LUTEINIZING HORMONE; EFFECT OF INCREASING DOSAGES OF LH UPON MEAN WEIGHT OF OVARIES COMPARED WITH CONTROL GROUP

\begin{tabular}{|c|c|c|c|c|c|}
\hline Group & $\begin{array}{c}\text { No. } \\
\text { animals }\end{array}$ & Dose ( $\mu g)$ & $\begin{array}{l}\text { Ovaries mean wt } \\
(m g) \pm \mathrm{s} . \mathrm{D}\end{array}$ & $t$ & $P$ \\
\hline Control & 5 & & $9 \cdot 2 \pm 2 \cdot 81$ & & \\
\hline Ovine LH NIH-LH-S4 & $\begin{array}{r}6 \\
11 \\
8 \\
4 \\
3 \\
4 \\
4 \\
2\end{array}$ & $\begin{array}{r}5 \\
10 \\
20 \\
40 \\
80 \\
160 \\
320 \\
640\end{array}$ & $\begin{array}{l}11 \cdot 3 \pm 5 \cdot 07 \\
10 \cdot 7 \pm 5 \cdot 0 \\
11 \cdot 5 \pm 4 \cdot 67 \\
13 \cdot 1 \pm 4 \cdot 19 \\
12.9 \pm 3 \cdot 19 \\
20 \cdot 7 \pm 9 \cdot 62 \\
11 \cdot 5 \pm 3 \cdot 55 \\
15 \cdot 1\end{array}$ & $\begin{array}{l}0.787 \\
0.627 \\
0.978 \\
1.654 \\
1.716 \\
2.582 \\
1.057\end{array}$ & $\begin{array}{l}0.5 \text { to } 0.4 \\
0.6 \text { to } 0.5 \\
0.4 \text { to } 0.3 \\
0.2 \text { to } 0.1 \\
0.2 \text { to } 0.1 \\
0.05 \text { to } 0.02 \\
0.4 \text { to } 0.3\end{array}$ \\
\hline $\begin{array}{l}\text { Ovine } \mathrm{LH} \text { NIH-LH-S4 repeated } \\
\text { assay }\end{array}$ & $\begin{array}{l}4 \\
6 \\
5 \\
4\end{array}$ & $\begin{array}{r}40 \\
80 \\
160 \\
320\end{array}$ & $\begin{array}{r}10 \cdot 1 \pm 1.42 \\
13.2 \pm 3.97 \\
11.9 \pm 3.01 \\
9 \cdot 6 \pm 2.94\end{array}$ & $\begin{array}{l}0.520 \\
1.842 \\
1.443 \\
0.187\end{array}$ & $\begin{array}{ll} & 0.6 \\
0.1 & \\
0.2 \\
0.9 & \text { to } 0.8\end{array}$ \\
\hline Ovine LH NIH-LH-s3 & 3 & 466 & $14.7 \pm 5 \cdot 85$ & $1 \cdot 845$ & 0.1 to 0.2 \\
\hline Control & 5 & & $10 \cdot 5 \pm 4 \cdot 66$ & & \\
\hline Ovine LH NIH-LH-s6 & $\begin{array}{l}9 \\
2\end{array}$ & $\begin{array}{l}1000 \\
2000\end{array}$ & $\underset{9 \cdot 9}{20 \cdot 2} \pm 4 \cdot 71$ & $4-47$ & $<0.001$ \\
\hline Control & 5 & & $9 \cdot 2 \pm 2 \cdot 81$ & & \\
\hline Human LH IRC2 & $\begin{array}{l}6 \\
4 \\
6 \\
6\end{array}$ & $\begin{array}{r}5 \\
10 \\
20 \\
40\end{array}$ & $\begin{array}{l}14 \cdot 6 \pm 2 \cdot 81 \\
15 \cdot 2 \pm 5 \cdot 26 \\
21 \cdot 1 \pm 10 \cdot 2 \\
18 \cdot 3 \pm 4 \cdot 64\end{array}$ & $\begin{array}{l}4 \cdot 252 \\
2 \cdot 194 \\
2 \cdot 493 \\
3 \cdot 827 \\
\end{array}$ & $\begin{array}{l}0.01 \text { to } 0.001 \\
0.1 \text { to } 0.05 \\
0.05 \text { to } 0.02 \\
0.01 \text { to } 0.001\end{array}$ \\
\hline Human LH DEAE-fraction 2 & $\begin{array}{l}2 \\
4 \\
2\end{array}$ & $\begin{array}{l}10 \\
20 \\
40\end{array}$ & $\begin{array}{l}11 \cdot 6 \\
12 \cdot 8 \pm 2 \cdot 03 \\
22 \cdot 1\end{array}$ & $2 \cdot 148$ & 0.1 to 0.05 \\
\hline $\begin{array}{l}\text { Human pituitary gonadotrophin } \\
\text { LH fraction } \mathrm{CM}_{2}\end{array}$ & $\begin{array}{l}5 \\
7 \\
4 \\
3 \\
3\end{array}$ & $\begin{array}{r}40 \\
80 \\
160 \\
320\end{array}$ & $\begin{array}{l}15 \cdot 7 \pm 3 \cdot 78 \\
24 \cdot 5 \pm 6 \cdot 85 \\
27 \cdot 5 \pm 4 \cdot 04 \\
40 \cdot 9 \pm 10 \cdot 4\end{array}$ & $\begin{array}{l}3 \cdot 056 \\
4 \cdot 674 \\
8 \cdot 03 \\
6 \cdot 746\end{array}$ & $\begin{array}{c}0.01 \text { to } 0.02 \\
0.001 \\
<0.001 \\
0.001\end{array}$ \\
\hline
\end{tabular}

In the ovaries of mice given $466 \mu \mathrm{g}$ NIH-LH-s3 the follicles remained small, and corpora lutea were numerous. Their capillary spaces were narrow and the luteal cells were small with finely granular cytoplasm of normal appearance. The interstitial cells were normal. Similar results were obtained with NIH-LH-s6 at 1000 and $2000 \mu \mathrm{g}$ respectively.

Human luteinizing hormone (Tables 4 and 5; Text-fig. 3; Pl. 2, Figs. 5 and 6). 
The IRC2 fraction of human luteinizing hormone was assayed at dosages between 5 and $40 \mu \mathrm{g}$. The ovarian weight was above the control level $(P=0.05$ to 0.001 ) and rose only slightly with increase of the dosage. The uterine weight curve was flat but significantly higher than the control $(P=0.05$ to 0.001$)$. The decidual response occurred in mice given dosages of 20 and $40 \mu \mathrm{g}$ but not 5 and $10 \mu \mathrm{g}$. The slope of the dose-response curve was steep.

The DEAE-fraction 2 of human luteinizing hormone was used only for pilot assays due to the shortage of the material. It was assayed at dosages of 10,20 and $40 \mu \mathrm{g}$ respectively. Both the intact uterine horn and the ovaries showed a moderate gain in weight and deciduomata occurred in mice given either 20 or $40 \mu \mathrm{g}$.

\section{TABLE 6}

HYPOPHYSECTOMIZED MICE TREATED WITH PREPARATIONS OF HUMAN AND BOVINE GROWTH HORMONE; EFFEGT OF INCREASING DOSAGES OF GROWTH HORMONE UPON MEAN WEIGHT OF INTACT UTERINE HORNS COMPARED WITH CONTROL GROUP

\begin{tabular}{|c|c|c|c|c|c|}
\hline Group & $\begin{array}{c}\mathcal{N} o . \\
\text { animals }\end{array}$ & Dose ( $\mu \mathrm{g})$ & $\begin{array}{l}\text { Intact hom mean } \\
\text { wt }(\mathrm{mg}) \pm \text { S.D. }\end{array}$ & $t$ & $P$ \\
\hline Control & 20 & & $25 \cdot 2 \pm 5 \cdot 39$ & & \\
\hline Human growth hormone $\mathrm{my}-61$ & $\begin{array}{r}6 \\
10 \\
14 \\
16\end{array}$ & $\begin{array}{r}125 \\
250 \\
500 \\
1000\end{array}$ & $\begin{array}{l}21 \cdot 2 \pm 2 \cdot 54 \\
23 \cdot 3 \pm 3 \cdot 20 \\
23 \cdot 9 \pm 4 \cdot 48 \\
34 \cdot 0 \pm 8 \cdot 41\end{array}$ & $\begin{array}{c}-1.733 \\
-0.987 \\
-0.719 \\
3.91\end{array}$ & $\begin{array}{c}0.1 \\
0.3 \\
0.5 \text { to } 0.4 \\
<0.001\end{array}$ \\
\hline $\begin{array}{l}\text { Human growth hormone CMC } \\
\text { purified } M 12\end{array}$ & $\begin{array}{r}5 \\
12 \\
14\end{array}$ & $\begin{array}{l}125 \\
250 \\
500\end{array}$ & $\begin{array}{l}24 \cdot 4 \pm 3 \cdot 33 \\
28 \cdot 9 \pm 7 \cdot 27 \\
37 \cdot 6 \pm 5 \cdot 71\end{array}$ & $\begin{array}{c}-0.285 \\
2.69 \\
8.34\end{array}$ & $\begin{array}{l}0.8 \text { to } 0.7 \\
0.02 \text { to } 0.01 \\
<0.001\end{array}$ \\
\hline Control & 5 & & $25 \cdot 4 \pm 4 \cdot 21$ & & \\
\hline Human growth hormone JA-62 & $\begin{array}{l}4 \\
7\end{array}$ & $\begin{array}{l}1000 \\
2000\end{array}$ & $\begin{array}{l}29 \cdot 0 \pm 4 \cdot 68 \\
33 \cdot 0 \pm 4 \cdot 78\end{array}$ & $\begin{array}{l}1 \cdot 210 \\
2 \cdot 837\end{array}$ & $\begin{array}{c}0.3 \text { to } 0.2 \\
0.02\end{array}$ \\
\hline $\begin{array}{l}\text { Human growth hormone } \\
\text { fraction } 2 \text { DEAE- } 6\end{array}$ & $\begin{array}{l}4 \\
5\end{array}$ & $\begin{array}{l}250 \\
500\end{array}$ & $\begin{array}{l}28 \cdot 8 \pm 7 \cdot 37 \\
31 \cdot 1 \pm 4 \cdot 03\end{array}$ & $\begin{array}{l}0 \cdot 967 \\
2 \cdot 169\end{array}$ & $\begin{array}{l}0.4 \text { to } 0.3 \\
0.1 \text { to } 0.05\end{array}$ \\
\hline $\begin{array}{l}\text { Human growth hormone } \\
\text { fraction } 3 \text { DEAE- } 6\end{array}$ & $\begin{array}{l}3 \\
4\end{array}$ & $\begin{array}{l}250 \\
500\end{array}$ & $\begin{array}{l}28 \cdot 2 \pm 7 \cdot 82 \\
27 \cdot 9 \pm 6 \cdot 97\end{array}$ & $\begin{array}{l}0.674 \\
0.723\end{array}$ & $\begin{array}{c}0.6 \text { to } 0.5 \\
0.5\end{array}$ \\
\hline $\begin{array}{l}\text { Bovine growth hormone } \\
72-\text { GH-1 }\end{array}$ & $\begin{array}{l}8 \\
4 \\
4\end{array}$ & $\begin{array}{l}1000 \\
2000 \\
4000\end{array}$ & $\begin{array}{l}29 \cdot 5 \pm 4 \cdot 71 \\
35 \cdot 2 \pm 7 \cdot 28 \\
35 \cdot 1 \pm 5 \cdot 23\end{array}$ & $\begin{array}{l}1.573 \\
2.526 \\
3.068\end{array}$ & $\begin{array}{l}0.2 \text { to } 0.1 \\
0.05 \text { to } 0.02 \\
0.02 \text { to } 0.01\end{array}$ \\
\hline
\end{tabular}

In the ovaries of mice given IRC2 at dosages of 20 and $40 \mu \mathrm{g}$, follicles were mainly at the primary stage and only a few developed small antra. One Graafian follicle was found in one ovary only. Corpora lutea were generally present in moderate numbers and in some ovaries they were quite numerous. They were of medium size with closely packed cords of rather small luteal cells, and there was no hyperaemia. A very few follicles showed partially luteinized membrana granulosa with or without retained ova. In some ovaries the interstitial cells were hypertrophic and hyperplastic and in others they were normal.

The ovaries of mice given DEAE-fraction 2 in dosages of 20 and $40 \mu \mathrm{g}$ were similar to those of mice given $\mathrm{IRC}_{2}$ except that all the follicles were small. 
Human pituitary gonadotrophin (luteinizing fraction $\mathrm{CM}_{2}$ ) (Tables 4 and 5; Textfig. 3). This preparation was assayed at dosages ranging from 40 to $320 \mu \mathrm{g}$. Deciduomata were induced but the decidual dose-response curve showed a negative correlation and at $320 \mu \mathrm{g}$ the reaction was negative. Ovarian weight rose gradually to highly significant values and uterine weight was much higher than in normal mice and reached a plateau.

\section{TABLE 7}

HYPOPHYSECTOMIZED MIGE TREATED WITH PREPARATIONS OF HUMAN AND BOVINE GROWTH HORMONE; EFFECT OF INGREASING DOSAGES OF GROWTH HORMONE UPON MEAN WEIGHT OF OVARIES COMPARED WITH CONTROL GROUP

\begin{tabular}{|c|c|c|c|c|c|}
\hline Group & $\begin{array}{c}\text { No. } \\
\text { animals }\end{array}$ & Dose ( $\mu g)$ & $\begin{array}{l}\text { Ovaries mean wt } \\
(m g) \pm \mathrm{S} . \mathrm{D}\end{array}$ & $t$ & $P$ \\
\hline Control & 20 & & $10 \cdot 4 \pm 3 \cdot 95$ & & \\
\hline Human growth hormone $\mathrm{My}-61$ & $\begin{array}{r}6 \\
10 \\
14 \\
16\end{array}$ & $\begin{array}{r}125 \\
250 \\
500 \\
1000\end{array}$ & $\begin{array}{r}8 \cdot 1 \pm 2 \cdot 29 \\
8 \cdot 2 \pm 2 \cdot 19 \\
9 \cdot 9 \pm 2 \cdot 72 \\
12 \cdot 0 \pm 2 \cdot 32\end{array}$ & $\begin{array}{r}-1.344 \\
-1.652 \\
-0.335 \\
1.460\end{array}$ & $\begin{array}{l}0.2 \\
0.1 \\
0.8 \text { to } 0.7 \\
0.2 \text { to } 0.1\end{array}$ \\
\hline $\begin{array}{l}\text { Human growth hormone cMc } \\
\text { purified M } 12\end{array}$ & $\begin{array}{r}5 \\
12 \\
15\end{array}$ & $\begin{array}{l}125 \\
250 \\
500\end{array}$ & $\begin{array}{l}12 \cdot 3 \pm 2 \cdot 65 \\
12 \cdot 3 \pm 4 \cdot 57 \\
13 \cdot 5 \pm 4 \cdot 67\end{array}$ & $\begin{array}{l}1 \cdot 036 \\
1 \cdot 24 \\
2 \cdot 127\end{array}$ & $\begin{array}{l}\quad 0.3 \\
0.3 \text { to } 0.2 \\
0.05 \text { to } 0.02\end{array}$ \\
\hline Control & 5 & & $9 \cdot 2 \pm 2 \cdot 81$ & & \\
\hline Human growth hormone JA-62 & $\begin{array}{l}4 \\
7\end{array}$ & $\begin{array}{l}1000 \\
2000\end{array}$ & $\begin{array}{r}8 \cdot 9 \pm 2 \cdot 81 \\
11 \cdot 2 \pm 4 \cdot 19\end{array}$ & $\begin{array}{r}-0 \cdot 191 \\
0.904\end{array}$ & $\begin{array}{l}0.9 \text { to } 0.8 \\
0.4 \text { to } 0.3\end{array}$ \\
\hline $\begin{array}{l}\text { Human growth hormone } \\
\text { fraction } 2 \text { DEAE-6 }\end{array}$ & $\begin{array}{l}4 \\
5\end{array}$ & $\begin{array}{l}250 \\
500\end{array}$ & $\begin{array}{r}9 \cdot 8 \pm 2 \cdot 43 \\
10 \cdot 9 \pm 2 \cdot 95\end{array}$ & $\begin{array}{l}0.285 \\
0.889\end{array}$ & $\begin{array}{c}0.8 \text { to } 0.7 \\
0.4\end{array}$ \\
\hline $\begin{array}{l}\text { Human growth hormone } \\
\text { fraction } 3 \text { DEAE- } 6\end{array}$ & $\begin{array}{l}3 \\
4\end{array}$ & $\begin{array}{l}250 \\
500\end{array}$ & $\begin{aligned} 11 \cdot 8 & \pm 0 \cdot 72 \\
9 \cdot 9 & \pm 3 \cdot 41\end{aligned}$ & $\begin{array}{l}1.479 \\
0.381\end{array}$ & 0.8 to 0.7 \\
\hline $\begin{array}{l}\text { Bovine growth hormone } \\
\text { 72-GH-1 }\end{array}$ & $\begin{array}{l}8 \\
4 \\
4\end{array}$ & $\begin{array}{l}1000 \\
2000 \\
4000\end{array}$ & $\begin{array}{l}13 \cdot 7 \pm 3 \cdot 24 \\
13 \cdot 1 \pm 2 \cdot 27 \\
14 \cdot 9 \pm 1 \cdot 13\end{array}$ & $\begin{array}{l}2.548 \\
2 \cdot 216 \\
3.763\end{array}$ & $\begin{array}{l}0.05 \text { to } 0.02 \\
0.1 \text { to } 0.05 \\
0.01\end{array}$ \\
\hline
\end{tabular}

The ovaries of mice given $320 \mu \mathrm{g}$ contained growing and mature follicles, some of which showed partial luteinization of granulosa cells with or without retained ova. There were few corpora lutea; their cells were small and closely packed but retained the normal structure. The interstitial cells were hypertrophic.

\section{Growth hormone}

Human growth hormone (Tables 6 and 7; Text-fig 4; Pl. 2, Figs. 7 and 8). Five preparations of human growth hormone were assayed at dosages of between 125 and $2000 \mu \mathrm{g}$. With one exception the ovaries were small and not different in weight from those of the control group $(P>0.05)$. At low dosages the uterine weights were at the control level. They rose slowly but significantly $(P=0.05$ to 0.001 ) at higher dosages. All preparations produced deciduomata and the slope of the dose-response curves was steep.

The ovaries of mice given all preparations except human growth hormone 
JA-62 were examined histologically at higher dosage levels. Follicles were mainly at the primary stage and only in those given growth hormone My-61 were there follicles with moderate-sized antra. This may have been due to the follicular growth before hypophysectomy since the weight of the ovaries after the operation did not differ from the control group $(P>0.05)$. Corpora lutea were numerous and some of them had large luteal cells arranged in meshlike cords separated by wide capillary spaces. These cells had finely granular cytoplasm and vesicular nuclei. Other corpora lutea had small closely-packed cells. The interstitial cells were atrophied.

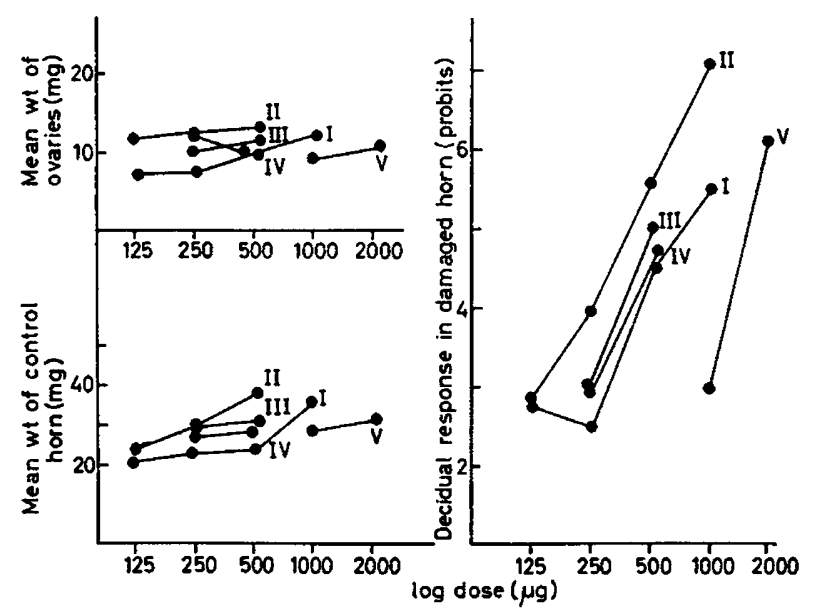

TeXT-FIG. 4. Hypophysectomized mice treated with human pituitary growth hormone (HGH). I. HGH MY-61. II. HGH, CMC purified M 12. III. HGH, fraction 2, DEAE-6. IV. HGH, fraction 3, DEAE-6. V. HGH, JA-62.

Bovine growth hormone (Tables 6 and 7). Preparations of bovine growth hormone were tested at dosages between 500 and $4000 \mu \mathrm{g}$. They produced deciduomata at higher dose levels and the slopes of the dose-response curves were steep. These preparations caused a slight increase in ovarian and uterine weights $(P=0.05$ to 0.01$)$.

The ovaries of mice given $4000 \mu \mathrm{g} 72-\mathrm{GH}-1$ were similar to those of mice given ovine prolactin.

Bovine thyrotrophin CMC/28/3 (Tables 8 and 9). This preparation was tested at dosages of 12.5 and 25 units per mouse. It had no effect on ovarian weight $(P>0.05)$ but caused a moderate enlargement of the intact uterine horn at the higher dose level $(P=0 \cdot 01)$. The decidual response occurred in mice given 25 units.

The ovaries of mice given 25 units did not differ histologically from those of mice given ovine prolactin.

Adrenocorticotrophic hormone (Tables 8 and 9). A preparation of adrenocorticotrophin (Armour) was tested at dosages of 4 and 8 units. The ovarian and uterine weights remained at the control level $(P>0.05)$ and no deciduomata developed.

The ovaries of mice given 4 units contained primary follicles, some with small 
antra. Corpora lutea were moderate in number and most had small denselyarranged cells. Others contained slightly larger cells with vacuolated cytoplasm. The interstitial cells were atrophic.

TABLE 8

HYPOPHYSECTOMIZED MIGE TREATED WITH PREPARATIONS OF THYROTROPHIN AND ADRENOCORTICOTROPHIN; EFFEGT OF INGREASING DOSAGES OF THE HORMONE UPON MEAN WEIGHT OF INTACT UTERINE HORNS COMPARED WITH CONTROL GROUP

\begin{tabular}{|c|c|c|c|c|c|}
\hline Group & $\underset{\text { No. }}{\text { Noimals }}$ & $\begin{array}{c}\text { Dose i.u.* } \\
(\mu g)\end{array}$ & $\begin{array}{l}\text { Intact horn mean } \\
w t(m g) \pm \text { S.D. }\end{array}$ & $t$ & $\dot{P}$ \\
\hline Control & 5 & & $25 \cdot 4 \pm 4 \cdot 21$ & & \\
\hline Bovine тsн смс/28/3 & $\begin{array}{l}3 \\
4\end{array}$ & $\begin{array}{r}500 \\
1000\end{array}$ & $\begin{array}{l}28 \cdot 7 \pm 3 \cdot 78 \\
36 \cdot 5 \pm 5 \cdot 37\end{array}$ & $\begin{array}{l}1 \cdot 082 \\
3 \cdot 475\end{array}$ & $\begin{array}{c}0.3 \text { to } 0.4 \\
0.01\end{array}$ \\
\hline AGTAR Armour Lab. FE 1401 & $\begin{array}{l}3 \\
4\end{array}$ & $\begin{array}{l}4 * \\
8 *\end{array}$ & $\begin{array}{l}24 \cdot 7 \pm 3 \cdot 41 \\
23 \cdot 7 \pm 4 \cdot 06\end{array}$ & $\begin{array}{l}-0.256 \\
-0.607\end{array}$ & $\begin{array}{c}0.8 \\
0.5 \text { to } 0.6\end{array}$ \\
\hline
\end{tabular}

TABLE 9

HYPOPHYSECTOMIZED MICE TREATED WITH PREPARATIONS OF THYROTROPHIN AND ADRENOCORTICOTROPHIN; EFFECT OF INGREASING DOSAGES OF THE HORMONE UPON MEAN WEIGHT OF OVARIES COMPARED WITH CONTROL GROUP

\begin{tabular}{|c|c|c|c|c|c|}
\hline Group & $\begin{array}{c}\text { No. } \\
\text { animals }\end{array}$ & $\begin{array}{l}\text { Dose i.u.* } \\
(\mu g)\end{array}$ & $\begin{array}{l}\text { Ovaries mean wt } \\
(\mathrm{mg}) \pm \text { S.D. }\end{array}$ & $t$ & $P$ \\
\hline Control & 5 & & $9 \cdot 2 \pm 2 \cdot 81$ & & \\
\hline Bovine Tsн $\mathrm{CMc} / 28 / 3$ & $\begin{array}{l}3 \\
4\end{array}$ & $\begin{array}{r}500 \\
1000\end{array}$ & $\begin{array}{r}8 \cdot 1 \pm 0.56 \\
11 \cdot 0 \pm 2 \cdot 09\end{array}$ & $\begin{array}{r}-0.673 \\
1.051\end{array}$ & $\begin{array}{l}0.6 \text { to } 0.5 \\
0.4 \text { to } 0.3\end{array}$ \\
\hline ACTAR Armour Lab. FE 1401 & $\begin{array}{l}3 \\
4\end{array}$ & $\begin{array}{l}4 * \\
8 *\end{array}$ & $\begin{array}{l}8 \cdot 8 \pm 1 \cdot 11 \\
8 \cdot 5 \pm 2 \cdot 55\end{array}$ & $\begin{array}{l}-0.252 \\
-0.391\end{array}$ & $\begin{array}{c}0.8 \\
0.7 \text { to } 0.8\end{array}$ \\
\hline
\end{tabular}

*i.u. ACTH

\section{PLACENTAL HORMONES}

\section{Human chorionic gonadotrophin}

Pregnyl Organon 9107 (Tables 10 and 11; Text-fig. 5; Pl. 3, Fig. 9). This preparation was tested at doses between 4 and 128 units. The ovaries and the intact uterine horns were similar in weight to those of normal mice. The decidual response occurred in mice given 32 units or more but it was negative in mice given 4,8 or 16 units. The slope of the dose-response curve was steep.

In ovaries of mice given 32, 64 and 128 units, follicles were mainly small and only a few showed small antra. Graafian follicles were extremely rare but corpora lutea were numerous and of medium size. Most were composed of small cells but some contained larger ones arranged in cords and separated by rather wider capillary spaces. A number of corpora lutea were completely vacuolated. The interstitial cells were hypertrophic. 
Chorionic gonadotrophin Leo (Tables 10 and 11; Text-fig. 5; Pl. 3, Figs. 10, 11 and 12). This was assayed at doses between 8 and 32 units. It caused a greater increase in ovarian weights than did Pregnyl. Deciduomata occurred in mice given 16 or 32 units.

TABLE 10

HYPOPHYSEGTOMIZED MIGE TREATED WITH VARIOUS PREPARATIONS OF PLAGENTAL GONADOTROPHIN; EFFECT OF INCREASING DOSAGES OF THE HORMONE UPON MEAN WEIGHT OF INTACT UTERINE HORNS COMPARED WITH CONTROL GROUP

\begin{tabular}{|c|c|c|c|c|c|}
\hline Group & $\underset{\text { No. }}{\text { Nonimals }}$ & $\begin{array}{l}\text { Dose i.u. CG* } \\
\text { u. PMS } \dagger(\mu g)\end{array}$ & $\begin{array}{l}\text { Intact horn mean } \\
w t(m g) \pm \text { S.D. }\end{array}$ & $t$ & $P$ \\
\hline Control & 5 & & $25 \cdot 4 \pm 4 \cdot 21$ & & \\
\hline $\begin{array}{l}\text { Human chorionic gonadotro- } \\
\text { phin Pregnyl Organon } 9107\end{array}$ & $\begin{array}{l}3 \\
4 \\
5 \\
3 \\
3 \\
4\end{array}$ & $\begin{array}{r}4^{*} \\
8^{*} \\
16^{*} \\
32^{*} \\
64^{*} \\
128^{*}\end{array}$ & $\begin{array}{l}37 \cdot 8 \pm 8 \cdot 58 \\
66 \cdot 0 \pm 22 \cdot 32 \\
45 \cdot 3 \pm 19 \cdot 16 \\
68 \cdot 6 \pm 9 \cdot 91 \\
48 \cdot 0 \pm 13 \cdot 0 \\
45 \cdot 3 \pm 11 \cdot 0\end{array}$ & $\begin{array}{l}2 \cdot 807 \\
4 \cdot 051 \\
2 \cdot 261 \\
8 \cdot 861 \\
3 \cdot 744 \\
3 \cdot 753\end{array}$ & $\begin{array}{l}0.05 \text { to } 0.02 \\
0.01 \text { to } 0.001 \\
0.05 \text { to } 0.1 \\
<0.001 \\
0.01 \\
0.01 \text { to } 0.001\end{array}$ \\
\hline $\begin{array}{l}\text { Chorionic gonadotrophin Leo } \\
162041\end{array}$ & $\begin{array}{l}5 \\
6 \\
5\end{array}$ & $\begin{array}{r}8^{*} \\
16^{*} \\
32^{*}\end{array}$ & $\begin{array}{l}65 \cdot 6 \pm 27 \cdot 84 \\
69 \cdot 6 \pm 19 \cdot 24 \\
53 \cdot 2 \pm 14 \cdot 07\end{array}$ & $\begin{array}{l}3 \cdot 185 \\
4 \cdot 997 \\
4 \cdot 231\end{array}$ & $\begin{array}{c}0.01 \\
<0.001 \\
0.01 \text { to } 0.001\end{array}$ \\
\hline $\begin{array}{l}\text { Pregnant mare serum gonado- } \\
\text { trophin Gestyl Organon } 9651\end{array}$ & $\begin{array}{l}6 \\
3 \\
4\end{array}$ & $\begin{array}{l}20 \dagger \\
40 \dagger \\
80 \dagger\end{array}$ & $\begin{array}{l}37 \cdot 5 \pm 12 \cdot 53 \\
48 \cdot 5 \pm 23 \cdot 75 \\
67 \cdot 1 \pm 22 \cdot 43\end{array}$ & $\begin{array}{l}2 \cdot 047 \\
3 \cdot 229 \\
4 \cdot 131\end{array}$ & $\begin{array}{l}0.1 \text { to } 0.05 \\
0.02 \text { to } 0.01 \\
0.01 \text { to } 0.001\end{array}$ \\
\hline Gestyl Organon 0048 & 4 & $160 \dagger$ & $64 \cdot 4 \pm 9 \cdot 33$ & $8 \cdot 466$ & $<0.001$ \\
\hline $\begin{array}{l}\text { Extract of pony endometrial } \\
\text { cup secretion }\end{array}$ & $\begin{array}{l}4 \\
4 \\
5 \\
4 \\
5 \\
4\end{array}$ & $\begin{array}{r}1 \\
2 \\
4 \\
8 \\
16 \\
32\end{array}$ & $\begin{array}{l}24 \cdot 2 \pm 8 \cdot 5 \\
28 \cdot 9 \pm 6 \cdot 84 \\
23 \cdot 9 \pm 6 \cdot 03 \\
27 \cdot 1 \pm 1 \cdot 92 \\
61 \cdot 5 \pm 19 \cdot 2 \\
60 \cdot 4 \pm 6 \cdot 43\end{array}$ & $\begin{array}{r}-0.288 \\
0.945 \\
-0.462 \\
0.701 \\
4.102 \\
9.874\end{array}$ & $\begin{array}{c}0.8 \text { to } 0.7 \\
0.4 \text { to } 0.3 \\
0.7 \text { to } 0.6 \\
0.5 \\
0.01 \text { to } 0.001 \\
<0.001\end{array}$ \\
\hline
\end{tabular}

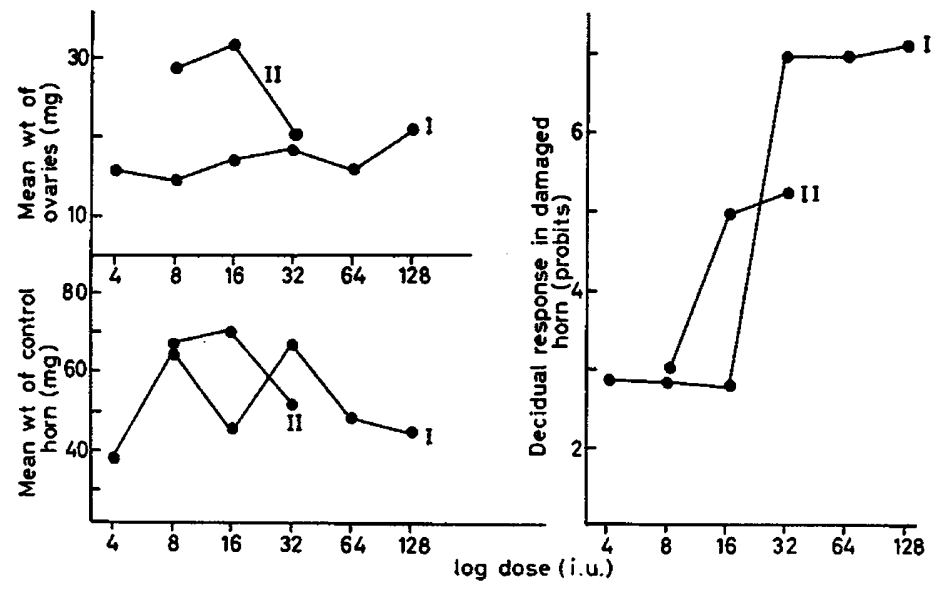

TeXT-FIG. 5. Hypophysectomized mice treated with human chorionic gonadotrophin. I. Pregnyl Organon, Lot 9107. II. Leo, Lot 162041. Dose-response curves of the ovaries and uterine horns. 
Ovaries of mice given 16 or 32 units were examined. Some contained Graafian or haemorrhagic follicles and others were built of corpora lutea. The maximum number of large follicles did not exceed three to four in one ovary. The theca interna cells were hypertrophic. The number of corpora lutea varied greatly. Some ovaries contained relatively small ones composed of small cells with dense cytoplasm which stained darkly with eosin. Others contained mainly vacuolated luteal cells. Some ovaries showed a great number of large corpora lutea with cells arranged in cords, but the cells were small. Only a few corpora lutea were composed of somewhat larger cells with pale and finely granular or foamy cytoplasm. Cell boundaries were well defined and nuclei vesicular. The interstitial cells were widespread and hypertrophic with granular eosinophilic cytoplasm. Their nuclei were mostly round or slightly elongated and their chromatin pattern was fine.

TABLE 11

HYPOPHYSECTOMIZED MICE TREATED WITH VARIOUS PREPARATIONS OF PLACENTAL GONADOTROPHIN; EFFECT OF INGREASING DOSAGES OF THE HORMONE UPON MEAN WEIGHT OF OVARIES COMPARED WITH CONTROL GROUP

\begin{tabular}{|c|c|c|c|c|c|}
\hline Group & $\begin{array}{c}\text { No. } \\
\text { animals }\end{array}$ & $\begin{array}{l}\text { Dose i.u. CG* } \\
\text { u. PMS† }(\mu g)\end{array}$ & $\begin{array}{l}\text { Ovaries mean wt } \\
\quad(m g) \pm \text { S.D. }\end{array}$ & $t$ & $P$ \\
\hline Control & 5 & & $9 \cdot 2 \pm 2 \cdot 81$ & & \\
\hline $\begin{array}{l}\text { Human chorionic gonadotro- } \\
\text { phin Pregnyl Organon } 9107\end{array}$ & $\begin{array}{l}3 \\
4 \\
5 \\
3 \\
3 \\
4\end{array}$ & $\begin{array}{r}4^{*} \\
8^{*} \\
16^{*} \\
32^{*} \\
64^{*} \\
128^{*}\end{array}$ & $\begin{array}{l}15 \cdot 7 \pm 3 \cdot 1 \\
15 \cdot 3 \pm 3 \cdot 72 \\
17 \cdot 6 \pm 8 \cdot 05 \\
19 \cdot 1 \pm 3 \cdot 41 \\
16 \cdot 3 \pm 1 \cdot 51 \\
21 \cdot 9 \pm 2 \cdot 14\end{array}$ & $\begin{array}{l}3 \cdot 054 \\
2 \cdot 801 \\
2 \cdot 201 \\
4 \cdot 449 \\
3 \cdot 915 \\
5 \cdot 696\end{array}$ & $\begin{array}{l}0.02 \text { to } 0.05 \\
0.05 \text { to } 0.02 \\
0.05 \text { to } 0.1 \\
0.01 \text { to } 0.001 \\
0.01 \text { to } 0.001 \\
<0.001\end{array}$ \\
\hline $\begin{array}{l}\text { Ghorionic gonadotrophin Leo } \\
162041\end{array}$ & $\begin{array}{l}5 \\
6 \\
5\end{array}$ & $\begin{array}{r}8^{*} \\
16^{*} \\
32^{*}\end{array}$ & $\begin{array}{l}28 \cdot 8 \pm 10 \cdot 9 \\
32 \cdot 9 \pm 7 \cdot 13 \\
21 \cdot 7 \pm 9 \cdot 15\end{array}$ & $\begin{array}{l}3 \cdot 872 \\
6 \cdot 94 \\
2 \cdot 901\end{array}$ & $\begin{array}{c}0.01 \text { to } 0.001 \\
<0.001 \\
0.02\end{array}$ \\
\hline $\begin{array}{l}\text { Pregnant mare serum gonado- } \\
\text { trophin Gestyl Organon } 9651\end{array}$ & $\begin{array}{l}6 \\
3 \\
4\end{array}$ & $\begin{array}{l}20 \dagger \\
40 \dagger \\
80 \dagger\end{array}$ & $\begin{array}{l}16 \cdot 2 \pm 5 \cdot 41 \\
12 \cdot 8 \pm 1 \cdot 2 \\
21 \cdot 6 \pm 3 \cdot 89\end{array}$ & $\begin{array}{l}2 \cdot 597 \\
2 \cdot 033 \\
5 \cdot 555\end{array}$ & $\begin{array}{l}0.05 \text { to } 0.02 \\
0.1 \text { to } 0.05 \\
<0.001\end{array}$ \\
\hline Gestyl Organon 0048 & 4 & $160 \dagger$ & $37 \cdot 8 \pm 12 \cdot 7$ & $4 \cdot 959$ & 0.01 to 0.001 \\
\hline $\begin{array}{l}\text { Extract of pony endometrial } \\
\text { cup secretion }\end{array}$ & $\begin{array}{l}4 \\
4 \\
5 \\
4 \\
5 \\
4\end{array}$ & $\begin{array}{r}1 \\
2 \\
4 \\
8 \\
16 \\
32\end{array}$ & $\begin{array}{r}9 \cdot 8 \pm 4 \cdot 75 \\
18 \cdot 1 \pm 2 \cdot 88 \\
13 \cdot 2 \pm 6 \cdot 99 \\
12 \cdot 1 \pm 2 \cdot 23 \\
17 \cdot 5 \pm 4 \cdot 18 \\
23 \cdot 3 \pm 2 \cdot 68\end{array}$ & $\begin{array}{l}0.221 \\
4 \cdot 649 \\
1 \cdot 186 \\
1 \cdot 638 \\
3 \cdot 682 \\
6 \cdot 951\end{array}$ & $\begin{array}{l}0.9 \text { to } 0.8 \\
0.01 \text { to } 0.001 \\
0.3 \text { to } 0.2 \\
0.2 \text { to } 0.1 \\
0.01 \text { to } 0.001 \\
\quad<0.001\end{array}$ \\
\hline
\end{tabular}

Pregnant mare serum gonadotrophic hormone (Tables 10 and 11; Text-fig. 6; Pl. 4, Figs. 13 and 14). Two batches of the pregnant mare serum gonadotrophin were assayed. Gestyl 9651 was tested at dosages of 20, 40 or 80 units and Gestyl 0048 at 160 units. Both preparations caused an increase in weight of the ovaries and uteri but the decidual response only occurred with the first preparation at a dosage of 80 units and was negative with the second at 160 units. The uterine dose-response curve increased gradually with Gestyl 9651. 
In the ovaries of mice given Gestyl 9651 at doses of 40 units the follicles were small with occasional antra. Corpora lutea were numerous and composed of small cells. Interstitial cells were stimulated but remained of normal size. Their cytoplasm was pale and finely granular and their nuclei were oval. At doses of 80 units some follicles were larger and a few were mature. Corpora lutea were numerous and of moderate size with mostly small but occasionally slightly larger cells. Their cytoplasm was pale and finely granular or foamy. Most corpora lutea showed distinct capillary spaces between the cords of luteal cells but there was no hyperaemia. Interstitial cells were hypertrophic.

The ovaries of mice given Gestyl 0048 at a dose of 160 units showed a different picture. They contained mainly growing and mature follicles. Some showed partially luteinized granulosa cells. Corpora lutea were scarce and their cells small. Interstitial cells were hypertrophic and hyperplastic.

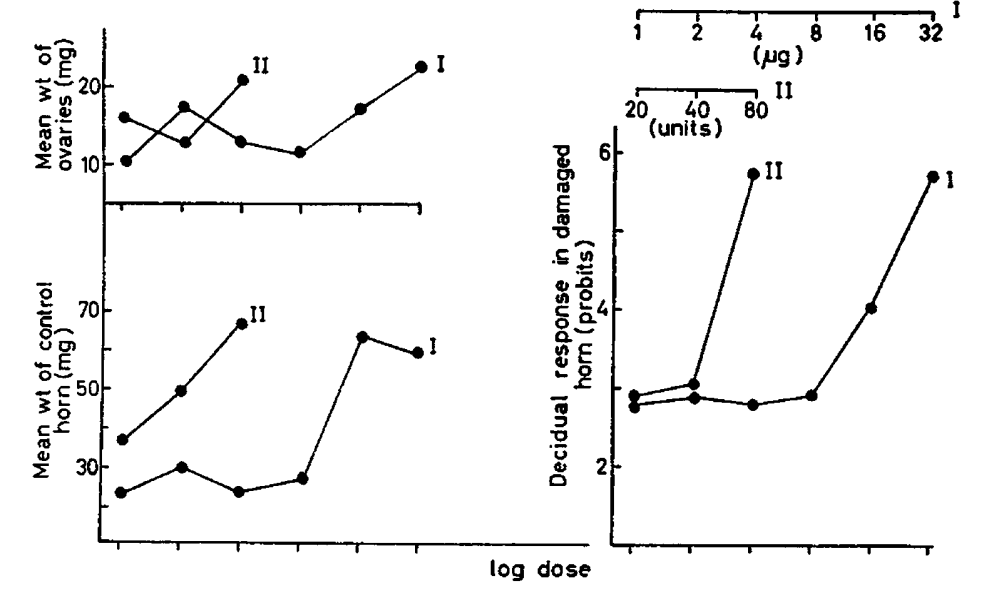

TEXT-FIG. 6. Hypophysectomized mice treated with $I$, the extract of pony endometrial cup secretion, and II, the pregnant mare serum gonadotrophin (Gestyl Organon 9651), respectively. Dose-response curves of the ovaries and uterine horns.

Pony endometrial cup secretion (Tables 10 and 11; Text-fig. 6; Pl. 4, Figs. 15 and 16). An extract of endometrial cup secretion from ponies was assayed at dosages of between 1 and $32 \mu \mathrm{g}$. The weight of the ovaries and of the intact horns increased gradually with doses of 16 and $32 \mu \mathrm{g}$. There was a rise in ovarian weight at $2 \mu \mathrm{g}$ but this was not accompanied by a significant increase in uterine weight. Deciduomata were produced in increasing number with doses of $16 \mu \mathrm{g}$ and $32 \mu \mathrm{g}$.

The ovaries of mice given $16 \mu \mathrm{g}$ contained a moderate number of corpora lutea. Most were composed of small cells with dense cytoplasm staining darkly with eosin, but some contained small cells with foamy or completely vacuolated pale eosinophilic cytoplasm. The ovaries of mice given $32 \mu \mathrm{g}$ of the preparation showed a great number of growing and mature follicles. A few were haemorrhagic and others partially luteinized. Corpora lutea were scarce and luteal cells were small. Interstitial cells were hypertrophic and hyperplastic. 


\section{SUMMARY OF RESULTS OF DECIDUOMA ASSAYS}

The results of assays of preparations with biological characteristics similar to ovine prolactin are shown in Table 12. These included human growth hormone, bovine growth hormone and bovine thyrotrophin. Some results of assays for ovine prolactin are also included for comparison and they agree reasonably well with the makers' estimates of their potency by the pigeon crop sac method. It will be noticed that preparations of growth hormone of human origin contained 2 to 12 units/mg of luteotrophin, bovine growth hormone 2 to 4 units/mg and bovine thyrotrophin 3 units $/ \mathrm{mg}$.

TABLE 12

RESUlTS OF ASSAYS OF OVINE PROLAGTIN, HUMAN GROWTH HORMONE, BOVINE GROWTH HORMONE AND BOVINE THYROTROPHIN BY THE DECIDUOMA METHOD; RESULTS ARE IN TERMS OF THE SECOND INTERNATIONAL STANDARD FOR PROLACTIN (POTENCY 22 I.U./MG)

\begin{tabular}{|c|c|c|c|c|}
\hline Preparation & $\begin{array}{l}\text { Result } \mathrm{mg} / \mathrm{mg} \\
\text { standard with } 95 \% \\
\quad \text { fd. limits }\end{array}$ & $\begin{array}{c}\text { Index of } \\
\text { precision } \\
\lambda\end{array}$ & $\begin{array}{l}\text { Result i.u./mg } \\
\text { with } 95 \% \text { fid. } \\
\quad \text { limits }\end{array}$ & $\begin{array}{c}\text { Mean } \\
\text { result } \\
(i . u . / m g)\end{array}$ \\
\hline Ovine prolactin Armour $759-39$ BB & $\begin{array}{l}1.19(0.69 \text { to } 2.23) \\
1.00(0.76 \text { to } 1.33)\end{array}$ & $\begin{array}{l}0 \cdot 22 \\
0 \cdot 16\end{array}$ & $\begin{array}{l}26 \cdot 2(15 \cdot 2 \text { to } 49 \cdot 1) \\
22 \cdot 0(16 \cdot 7 \text { to } 29 \cdot 3)\end{array}$ & $24 \cdot 1$ \\
\hline Panlitar Armour s 10209 & $1.20(0.71$ to 2.06$)$ & $0 \cdot 21$ & $26 \cdot 4(15 \cdot 6$ to $45 \cdot 3)$ & \\
\hline Human growth hormone my- 61 & $\begin{array}{l}0.29(0.17 \text { to } 0.51) \\
0.15(0.09 \text { to } 0.32) \\
0.21(0.03 \text { to } 0.44)\end{array}$ & $\begin{array}{l}0.21 \\
0.09 \\
0 \cdot 19\end{array}$ & $\begin{array}{l}6.4(3.7 \text { to } 11.2) \\
3.3(2.0 \text { to } 7 \cdot 0) \\
4.6(0.7 \text { to } 9.7)\end{array}$ & $4 \cdot 8$ \\
\hline $\begin{array}{l}\text { Human growth hormone cMc } \\
\text { purified }{ }_{\mathrm{M}} 12\end{array}$ & $0.56(0.32$ to 0.99$)$ & $0 \cdot 20$ & $12.3(7 \cdot 0$ to $21 \cdot 8)$ & \\
\hline Human growth hormone JA-62 & $\begin{array}{l}0.07(0.05 \text { to } 0.12) \\
0.11(0.05 \text { to } 0.23)\end{array}$ & $\begin{array}{l}0 \cdot 10 \\
0 \cdot 13\end{array}$ & $\begin{array}{l}1.5(1.1 \text { to } 2 \cdot 6) \\
2.4(1.1 \text { to } 5 \cdot 1)\end{array}$ & $1 \cdot 95$ \\
\hline $\begin{array}{l}\text { Human growth hormone fraction } 2 \\
\text { DEAE-6 }\end{array}$ & $0.23(0.09$ to 0.44$)$ & $0 \cdot 14$ & $5 \cdot 1(2 \cdot 0$ to $9 \cdot 7)$ & \\
\hline $\begin{array}{l}\text { Human growth hormone fraction } 3 \\
\text { DEAE-6 }\end{array}$ & $0.25(0.1$ to 0.52$)$ & $0 \cdot 13$ & $5 \cdot 5(2 \cdot 2$ to $11 \cdot 4)$ & \\
\hline Bovine growth hormone $72-\mathrm{GH}-1$ & $0.12(0.07$ to 0.29$)$ & $0 \cdot 21$ & $2.6(1.5$ to 6.4$)$ & \\
\hline Bovine growth hormone $99 \mathrm{~L}$ & $0.17(0.11$ to 0.32$)$ & $0 \cdot 10$ & $3.7(2.4$ to 7.0$)$ & \\
\hline Bovine тsн смс $/ 28 / 3$ & $0.12(0.05$ to 0.25$)$ & $0 \cdot 13$ & $2.6(1.1$ to 5.5$)$ & \\
\hline
\end{tabular}

The results of assays of human luteinizing hormone, chorionic gonadotrophin Leo and pony endometrial cup secretion are summarized in Table 13. They were expressed in terms of the Second International Standard Prolactin because their slopes were similar and parallel. It will be noticed that these preparations were five to eleven times more active than ovine prolactin. Chorionic gonadotrophin Pregnyl was compared with that of chorionic gonadotrophin Leo and its potency was only $62 \%$ (95\% fiducial limits 44 to 101 ). The decidual doseresponse curve of the pregnant mare serum gonadotrophin Gestyl 9651 was also similar to that of ovine prolactin and one ampoule of this preparation was equivalent to 14 units of luteotrophin. 
All assays were valid. The regression of the response curves was significant ( $\mathrm{g}=0.2$ to 0.6 ) and in no assay was there a departure from parallelism $(P>0.05)$. The index of precision, $\lambda$, varied between 0.08 and 0.21 .

TABLE 13

RESULTS OF ASSAYS OF HUMAN LUTEINIZING HORMONE, HUMAN CHORIONIC GONADOTROPHIN (LEO) AND AN EXTRACT OF ENDOMETRIAL GUP SECRETION BY THE DECIDUOMA METHOD; RESULTS ARE IN TERMS OF THE SECOND INTERNATIONAL STANDARD FOR PROLACTIN

\begin{tabular}{l|c|c}
\hline \multicolumn{1}{|c|}{ Preparation } & $\begin{array}{c}\text { Result mg/mg standard } \\
\text { with } 95 \% \text { fid. limits }\end{array}$ & $\begin{array}{c}\text { Index of } \\
\text { precision } \lambda\end{array}$ \\
\hline Human luteinizing hormone IRC2 & $6.92(4.33$ to 11.80$)$ & 0.11 \\
\hline Human chorionic gonadotrophin Leo 162041 & $11.38(6.07$ to 19.31$)$ & 0.13 \\
\hline Pony endometrial cup secretion & $5.24(2.86$ to 20.96$)$ & 0.15 \\
\hline
\end{tabular}

\section{DISCUSSION}

In the present work the formation of deciduomata in the damaged uterine horn of the hypophysectomized mouse has been used as a parameter in the assay of luteotrophic activity but the enlargement of the intact horn and the development of follicles, corpora lutea and interstitial cells in the ovary has permitted an assessment of the other gonadotrophic hormones simultaneously.

Rats and mice are suitable for the assay of luteotrophic hormone because of the specific effect of luteotrophin on the corpus luteum and the fact that ovulation is not normally followed by pseudopregnancy. Hypophysectomy was performed on the first day of dioestrus and at that time the newly formed corpora lutea of ovulation were still hyperaemic and their cells large. In untreated hypophysectomized mice the corpora lutea persisted for the period of 6 days required for the assay but the hyperaemia soon subsided and they were not functional.

Ovine prolactin enlarged the luteal cells, maintained the hyperaemia of corpora lutea and stimulated their function. The ovarian weight remained the same as that of the untreated controls and there was no stimulation of follicular growth or of interstitial cells. These results are comparable with those reported by Evans, Simpson, Lyons \& Turpeinen (1941) in the rat.

Ovine luteinizing hormone, on the other hand, produced a poor or negative decidual response even at high dosages and corpora lutea were less hyperaemic and had small luteal cells. The interstitial cells in the ovaries were stimulated but remained small, as in normal ovaries. Human luteinizing hormone, however, induced the formation of deciduomata and its dose-response curve was similar to that of ovine prolactin. Corpora lutea resembled those of animals treated with ovine luteinizing hormone, but the interstitial cells were hypertrophic.

Human chorionic gonadotrophin, pregnant mare serum gonadotrophin and an extract of endometrial cup secretion from ponies behaved in a very similar way to human luteinizing hormone by inducing the formation of deciduomata, 
and their dose-response curves were parallel. Placental gonadotrophins also greatly enlarged the ovaries and the uterus, and the gonads contained a few Graafian follicles and hypertrophic interstitial cells. As in experiments with human and ovine luteinizing hormone the corpora lutea were not hyperaemic and luteal cells smaller but they showed a greater variety in their morphology.

There can be little doubt that the luteal cells are the source of progestagens when stimulated with prolactin but the present work throws doubt on the site of its production after treatment with preparations of luteinizing hormones because such preparations did not enlarge the luteal cells or maintain the hyperaemia of corpora lutea while stimulating the growth of interstitial cells.

The possibility remains that ovarian interstitial cells produce progestagens. This assumption, however, does not take account of the fact that ovine luteinizing hormone had a poor or negative effect on the formation of deciduomata.

Purified ovine and human follicle stimulating hormones did not induce the formation of deciduomata. These hormones completely altered the histological appearance of the ovaries. The corpora lutea diminished or disappeared and were replaced by numerous newly built Graafian follicles while the interstitial cells remained atrophic. However, with less pure preparations a decidual response occurred with lower but disappeared with higher dosages. This might possibly be taken as evidence that the progestagen was not derived from the interstitial cells, since these were now stimulated, but came from the corpora lutea which were present at lower dosages but were replaced by follicles at higher dosages. Similar effects were observed with gonadotrophin from the urine of postmenopausal women (unpublished data, 1963) and from pregnant mare serum but not with the extract of endometrial cup secretion. A second possibility is that the decidual response is due to progestagens derived from the interstitial cells but is inhibited by oestrogens at higher dose levels of gonadotrophin. However, the decidual response was not inhibited by a number of preparations which stimulated uterine growth by causing the release of oestrogens. On the other hand oestrogens are not indispensable for the decidual response and prolactin by itself was found to be capable of inducing deciduomata although the degree of the individual reaction was less intense than when it occurred in the uterus stimulated by oestrogens.

Human growth hormone also contained luteotrophin and its biological characteristics were similar to ovine prolactin. Likewise some preparations of bovine growth hormone and bovine thyrotrophin were also contaminated with small amounts of luteotrophin but adrenocorticotrophic hormone had no effect on the ovaries or uteri.

Ovine prolactin and human growth hormone gave quantitatively the same results both with the local pigeon crop sac and the deciduoma methods (Ferguson \& Wallace, 1961, I963; Evans, Ferguson \& Kovačić, 1962; Kovačić, 1962, I 963 ) but human chorionic gonadotrophin used by Stack-Dunne failed to stimulate the crop gland in pigeons (M. P. Stack-Dunne, personal communication, 1963). This would suggest that chorionic gonadotrophin and prolactin are different biological entities.

Although several gonadotrophic hormones induced the formation of deciduomata, they cannot all be classified as luteotrophins. It is suggested that a more 
convenient as well as a more accurate attribute for the biological characterization of a gonadotrophic hormone would be the term 'deciduotrophic'. At present it appears that the term 'luteotrophin' should be reserved for preparations which cause hypertrophy of luteal cells accompanied by hyperaemia of the corpora lutea and are deficient in other gonadotrophic activities.

The deciduoma assay appears to be a specific method for measuring progestagens, and both prolactin and luteinizing hormone give rise to a similar reaction in the damaged uterine horn. This suggests that the same ovarian hormone was responsible for the formation of deciduomata and seemed to justify the expression of the results in terms of the reference standard for prolactin. However, it is unlikely that the decidual response produced by LH was due to contamination with prolactin because of distinct morphological differences in the corpora lutea between the two groups.

\section{AGKNOWLEDGMENTS}

I wish to thank Dr A. C. Crooke for his advice and encouragement and Dr W. $\mathrm{R}$. Butt for help in providing the preparations of hormones from many workers and pharmaceutical laboratories mentioned earlier in this paper. My thanks are also due to Dr D. R. Bangham of the Department of Biological Standards, National Institute for Medical Research, London, for supplies of the Second International Standard for Prolactin and to the Endocrine Study Section of the National Institutes of Health, Bethesda, Maryland, U.S.A. for their generous gifts of the purified sheep FSH and LH.

$\mathrm{Mr}$ Lee and Mr Carrington in this hospital prepared the photomicrographs and Miss J. Stacey helped in drawing the graphs.

This work was supported by a grant to the author from the World Health Organization and later from Organon Laboratories Ltd.

The costs of the research were met from a grant from the United Birmingham Hospitals' Endowment Fund Medical Research Committee.

\section{REFERENCES}

Bangham, D. R., Mussett, M. V. \& Stack-Dunne, M. P. (1963) The 2nd International Standard for Prolactin. Bull. World Hlth Org. 29, 721.

Butt, W. R., Crooke, A. G., Cunningham, F.J. \& Kovačić, N. (1962) The biological assay of fractions of gonadotrophin from human pituitary glands. 7. Endocrin. 24, 223.

Butt, W. R., Crooke, A. G., Cunningham, F. J. \& Wolf, A. (1963) Biological and immunological properties of human pituitary follicle stimulating hormone obtained by starch gel electrophoresis. 7. Endocrin. 25, 541 .

Evans, A. J., Ferguson, K. A. \& Kovačić, N. (1962) A comparison of the biological activity of prolactin by three different methods of assay. 7 . Endocrin. 24, 245.

Evans, H. M., Simpson, M. E., Lyons, W. R. \& Turpeinen, K. (1941) Anterior pituitary hormones which favor the production of traumatic uterine placentomata. Endocrinology, 28, 933.

Ferguson, K. A. \& Wallace, A. L. G. (1961) Prolactin activity of human growth hormone. Nature, Lond. 190, 632.

Ferguson, K. A. \& Wallace, A. L. C. (1963) The characterization of pituitary hormones by starch gel electrophoresis. Recent Progr. Hormone Res. 19, 1.

Hartree, A., Butt, W. R. \& Kirkham, K. (1964) The separation and purification of human pituitary luteinizing and thyrotrophic hormones. 7. Endocrin. 29,61.

Kovačić, N. (1962) Luteotrophic activity of human growth hormone (Raben). Nature, Lond. $195,1210$. Kovačıć, N. (1963) The deciduoma assay. A method for measuring prolactin. 7. Endocrin. 28, 45. 


\section{EXPLANATION OF PLATES}

\section{PLATE 1}

Frg. 1. Hypophysectomized mice treated with $0.9 \%$ sodium chloride solution. Ovary. $\times 43$.

Fig. 2. Hypophysectomized mice treated with prolactin (2nd International Standard Prolactin), dose $260 \mathrm{\mu g}$ per mouse. Ovary. $\times 40$.

Frg. 3. Hypophysectomized mice treated with ovine follicle stimulating hormone (NIHFSH-s 1), dose $500 \mu \mathrm{g}$ per mouse. Ovary. $\times 41$.

Frg. 4. Hypophysectomized mice treated with ovine luteinizing hormone (NIH-LH-S4), dose $640 \mathrm{\mu g}$ per mouse. Ovary. $\times 45$.

\section{PLATE 2}

FIG. 5. Hypophysectomized mice treated with human luteinizing hormone (IRC 2 ), dose 40 ug per mouse. Ovary. $\times 28$.

Fig. 6. Hypophysectomized mice treated with human luteinizing hormone (IRC2), dose 40 ug per mouse. Deciduomata in the damaged uterine horn. $\times 32$.

Fig. 7. Hypophysectomized mice treated with human growth hormone (cma purified M 12), dose $0.5 \mathrm{mg}$ per mouse. Ovary, $\times 42$.

FIG. 8. Hypophysectomized mice treated with human growth hormone (fraction 2, DEAE-6), dose $0.5 \mathrm{mg}$ per mouse. Deciduoma in the damaged uterine horn. $\times 41$.

\section{PLATE 3}

Fig. 9. Hypophysectomized mice treated with chorionic gonadotrophin, Pregnyl Organon, Lot No. 9107, dose 6 i.u. per mouse. Ovary. $\times 50$.

Fig. 10. Hypophysectomized mice treated with chorionic gonadotrophin Leo, Lot No. 162041 , dose 16 i.u. per mouse. Ovary. $\times 32$.

Frg. 11. Hypophysectomized mice treated with chorionic gonadotrophin Leo, Lot No. 162041 , dose 32 i.u. per mouse. Ovary. $\times 28$.

FIG. 12. Hypophysectomized mice treated with chorionic gonadotrophin Leo, Lot No. 162041, dose 32 i.u. per mouse. Decidual reaction in the damaged uterine horn. $\times 25$.

\section{PLATE 4}

Fig. 13. Hypophysectomized mice treated with the pregnant mare serum gonadotrophin (Gestyl Organon 9651), dose 80 units per mouse. Ovary. $\times 42$.

FIG. 14. Hypophysectomized mice treated with the pregnant mare serum gonadotrophin (Gestyl Organon 0048), dose 160 units per mouse. Ovary. $\times 28$.

FIG. 15. Hypophysectomized mice treated with the extract of pony endometrial cup secretion, dose $16 \mu \mathrm{g}$ per mouse. Ovary. $\times 39$.

Fig. 16. Hypophysectomized mice treated with the extract of pony endometrial cup secretion, dose $32 \mu \mathrm{g}$ per mouse. Ovary. $\times 42$. 
PLATE 1

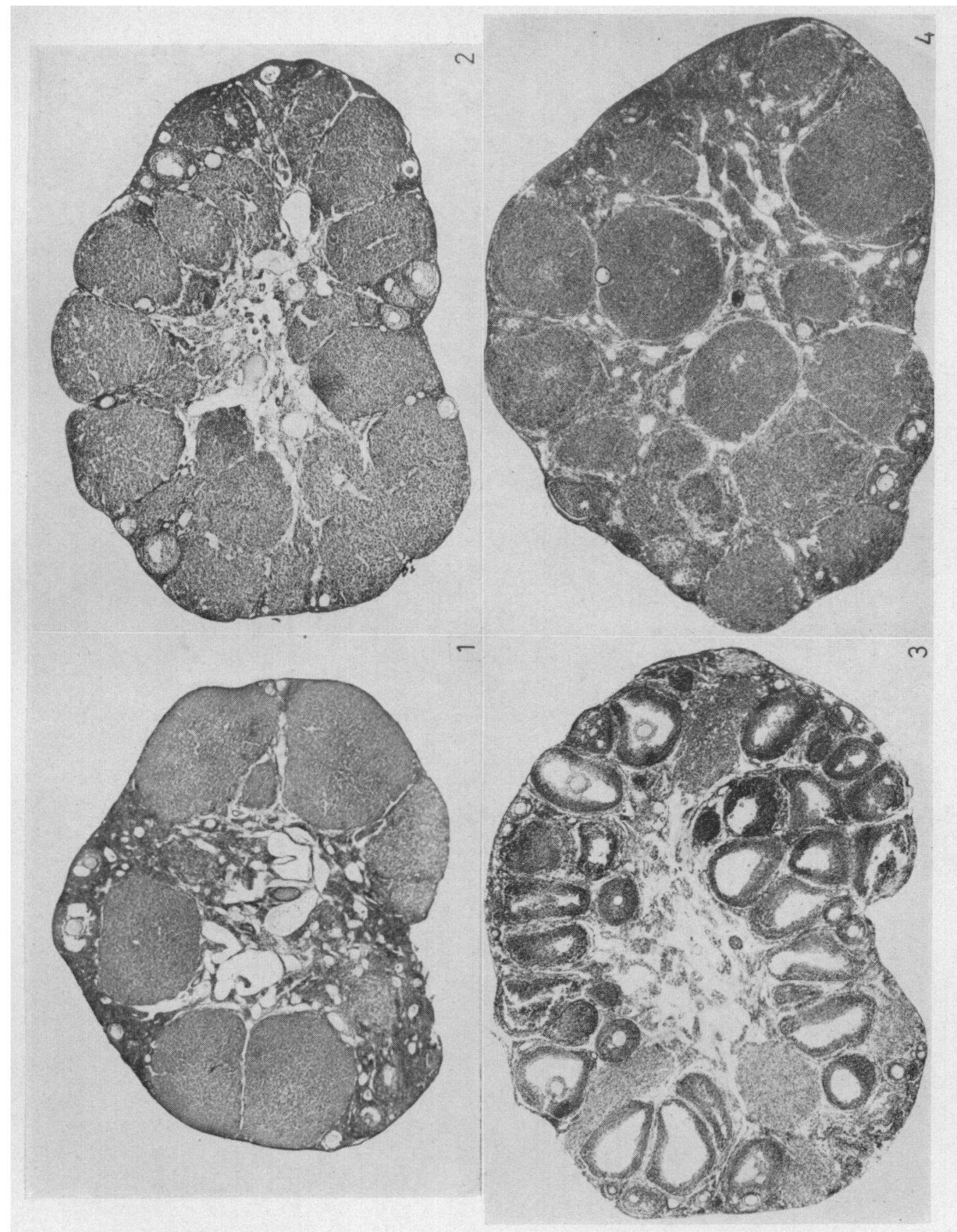

(Facing $p .186$ ) 
PI.ATE 2

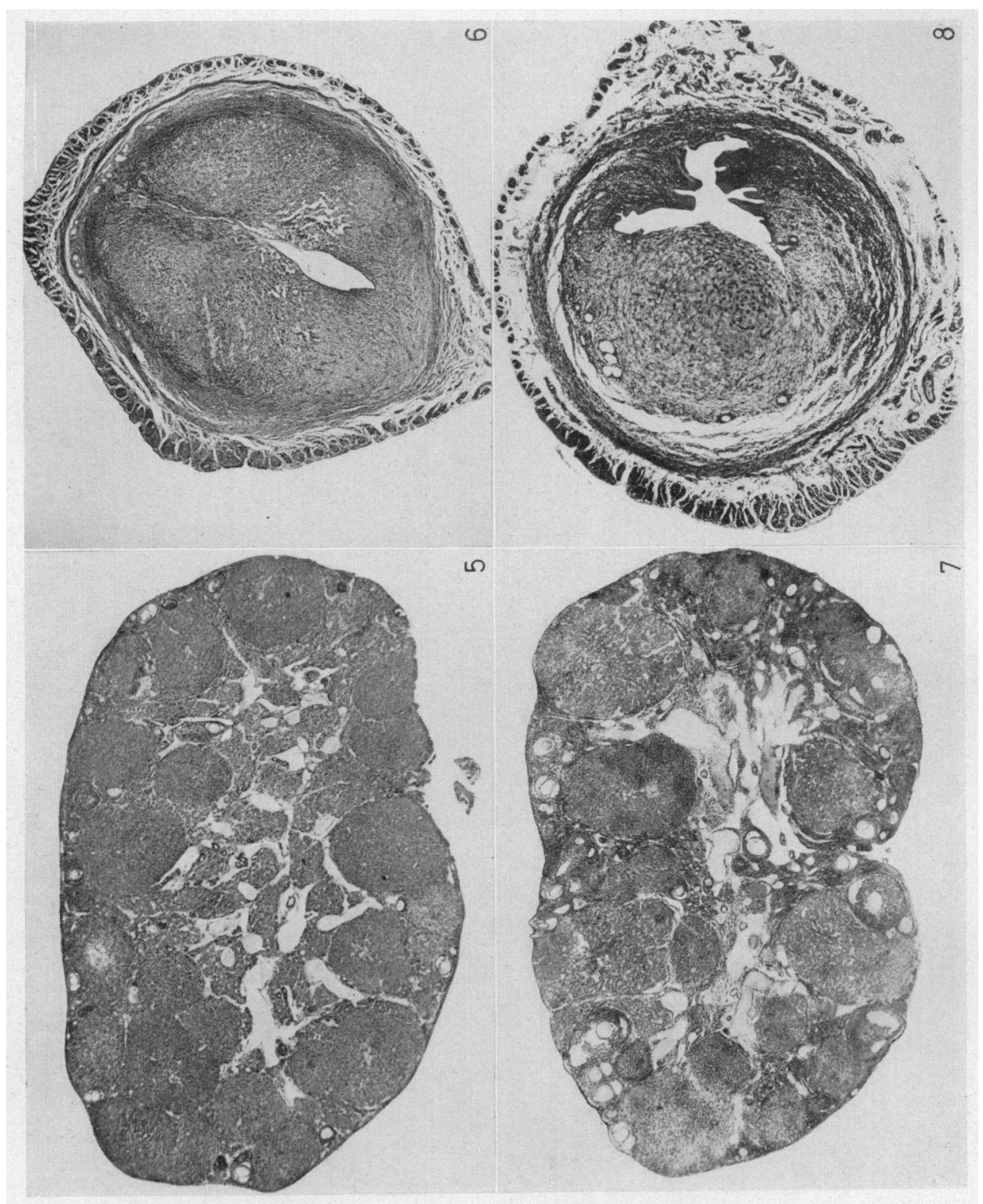




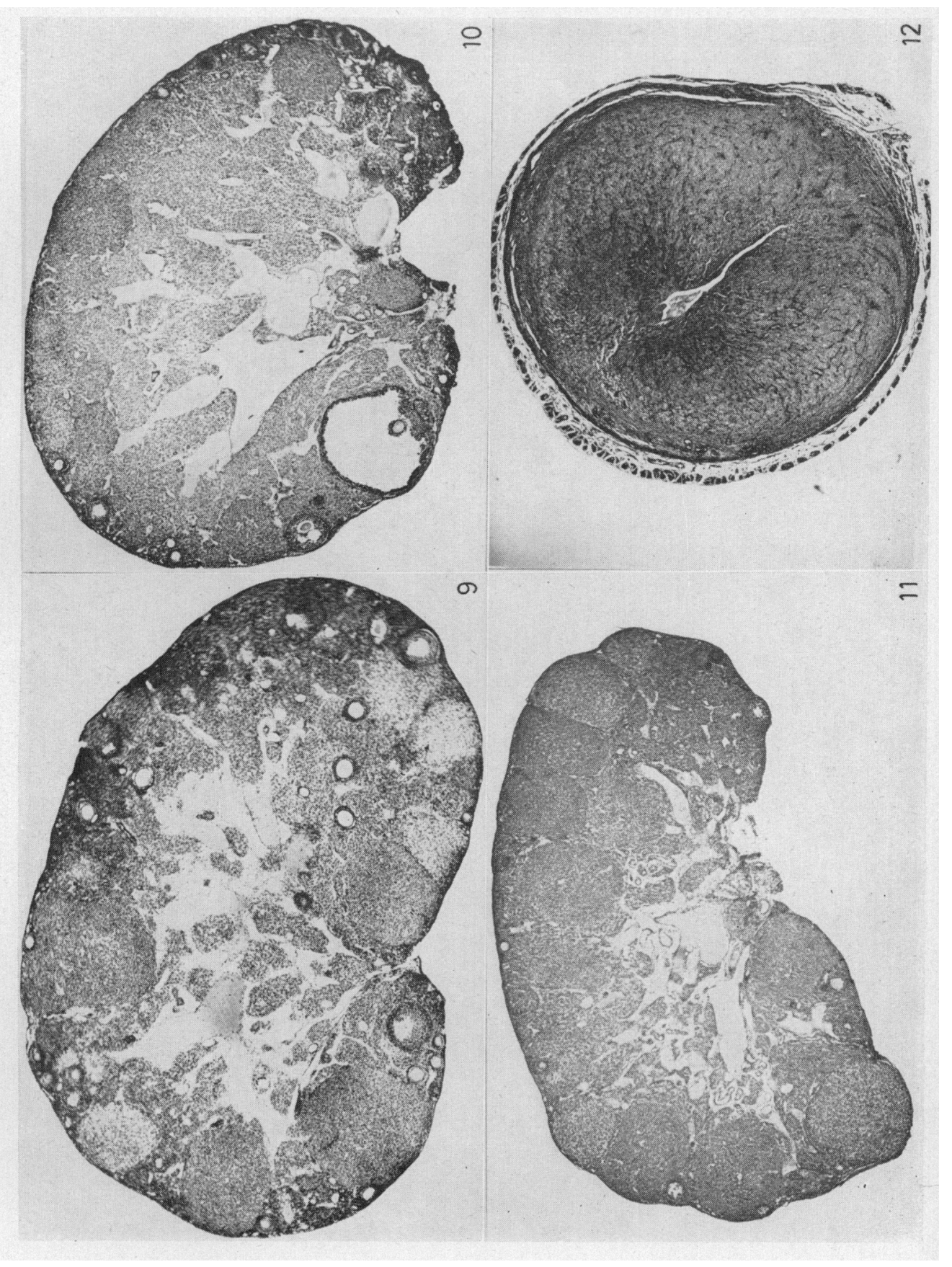


PLATE 4

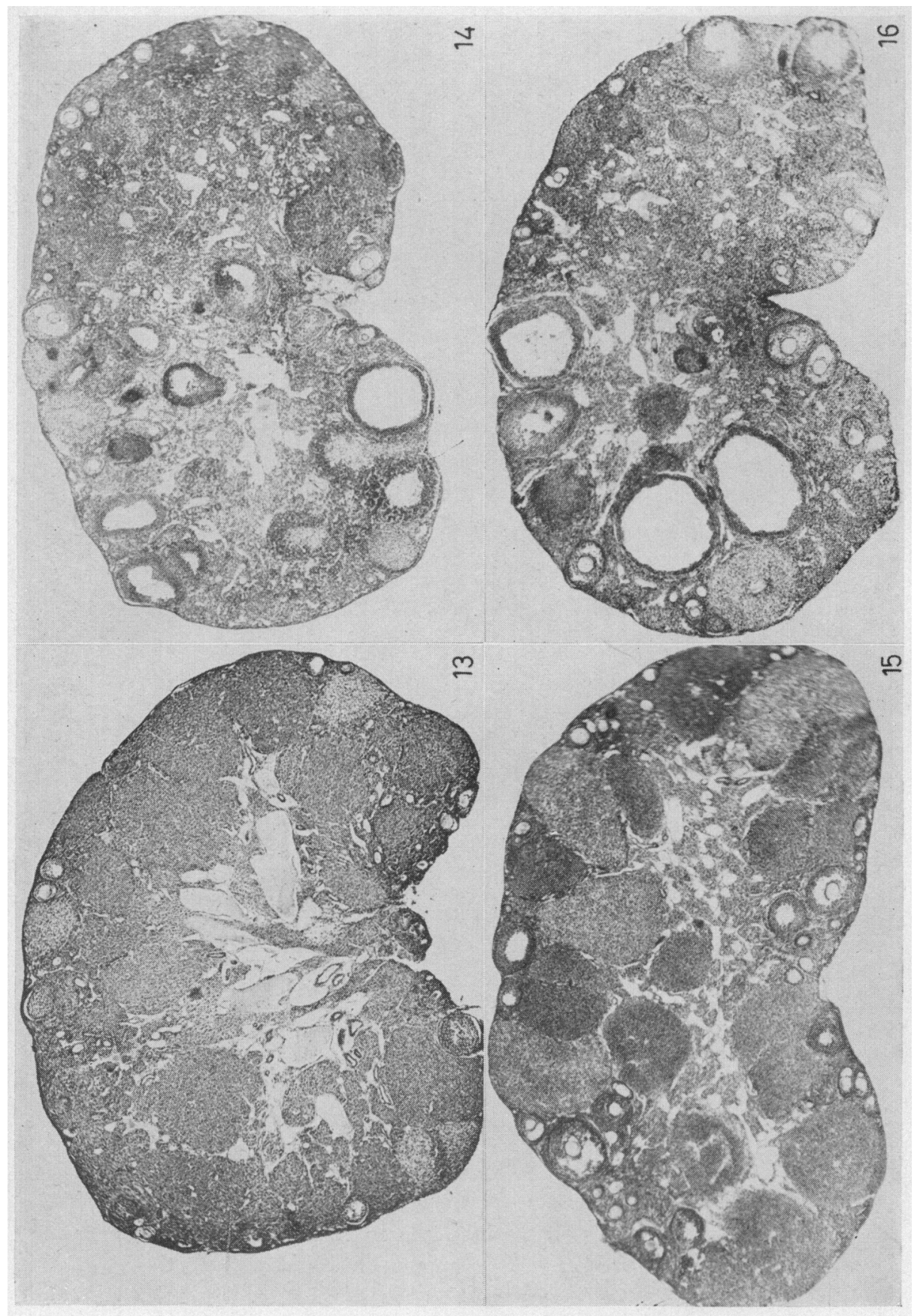

